\title{
Cysteinyl Leukotriene Pathway and Cancer
}

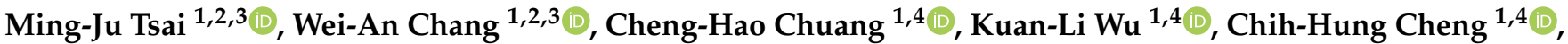 \\ Chau-Chyun Sheu ${ }^{1,2,3} \mathbb{D}$, Ya-Ling Hsu ${ }^{4}$ and Jen-Yu Hung $1,2,3,5, *$ \\ 1 Division of Pulmonary and Critical Care Medicine, Department of Internal Medicine, Kaohsiung Medical \\ University Hospital, Kaohsiung Medical University, Kaohsiung 807, Taiwan; \\ SiegfriedTsai@gmail.com (M.-J.T.); 960215kmuh@gmail.com (W.-A.C.); aeafish@gmail.com (C.-H.C.); \\ 980448kmuh@gmail.com (K.-L.W.); Markbruse617@gmail.com (C.-H.C.); sheucc@gmail.com (C.-C.S.) \\ 2 School of Medicine, College of Medicine, Kaohsiung Medical University, Kaohsiung 807, Taiwan \\ 3 Department of Respiratory Care, College of Medicine, Kaohsiung Medical University, Kaohsiung 807, Taiwan \\ 4 Graduate Institute of Medicine, College of Medicine, Kaohsiung Medical University, Kaohsiung 807, Taiwan; \\ yainghsu@kmu.edu.tw \\ 5 Department of Internal Medicine, Kaohsiung Municipal Ta-Tung Hospital, Kaohsiung Medical University, \\ Kaohsiung 807, Taiwan \\ * Correspondence: jenyuhung@gmail.com; Tel.: +886-7-3121101 (ext. 5651)
}

check for updates

Citation: Tsai, M.-J.; Chang, W.-A.; Chuang, C.-H.; Wu, K.-L.; Cheng, C.-H.; Sheu, C.-C.; Hsu, Y.-L.; Hung J.-Y. Cysteinyl Leukotriene Pathway and Cancer. Int. J. Mol. Sci. 2022, 23, 120. https://doi.org/10.3390/ ijms23010120

Academic Editor: Michael Welsh

Received: 19 November 2021

Accepted: 21 December 2021

Published: 23 December 2021

Publisher's Note: MDPI stays neutral with regard to jurisdictional claims in published maps and institutional affiliations.

Copyright: (C) 2021 by the authors. Licensee MDPI, Basel, Switzerland. This article is an open access article distributed under the terms and conditions of the Creative Commons Attribution (CC BY) license (https:// creativecommons.org/licenses/by/ $4.0 /)$.

\begin{abstract}
Cancer remains a leading cause of death worldwide, despite many advances being made in recent decades. Changes in the tumor microenvironment, including dysregulated immunity, may contribute to carcinogenesis and cancer progression. The cysteinyl leukotriene (CysLT) pathway is involved in several signal pathways, having various functions in different tissues. We summarized major findings of studies about the roles of the CysLT pathway in cancer. Many in vitro studies suggested the roles of CysLTs in cell survival/proliferation via CysLT 1 receptor $\left(\mathrm{CysLT}_{1} \mathrm{R}\right) . \mathrm{CysLT}_{1} \mathrm{R}$ antagonism decreased cell vitality and induced cell death in several types of cancer cells, such as colorectal, urological, breast, lung and neurological malignancies. CysLTs were also associated with multidrug resistance of cancer, and $\mathrm{CysLT}_{1} \mathrm{R}$ antagonism might reverse chemoresistance. Some animal studies demonstrated the beneficial effects of $\mathrm{CysLT}_{1} \mathrm{R}$ antagonist in inhibiting tumorigenesis and progression of some cancer types, particularly colorectal cancer and lung cancer. The expression of $\mathrm{CysLT}_{1} \mathrm{R}$ was shown in various cancer tissues, particularly colorectal cancer and urological malignancies, and higher expression was associated with a poorer prognosis. The chemo-preventive effects of $\mathrm{CysLT}_{1} \mathrm{R}$ antagonists were demonstrated in two large retrospective cohort studies. In summary, the roles of the CysLT pathway in cancer have been delineated, whereas further studies are still warranted.
\end{abstract}

Keywords: leukotriene; montelukast; zafirlukast; chemoprevention; cell death; apoptosis; $\mathrm{CysLT}_{1}$

\section{Unmet Need of Cancer Treatment}

Cancer is a major public health issue/concern worldwide and is the leading cause of death in many countries, including Taiwan [1,2]. Many types of procedures and medications are now available for cancer treatment, including surgery, radiotherapy, chemotherapeutic agents and targeted therapy. The development of immunotherapy seems to open a new era of cancer treatment. Check point inhibitor, one of the different types of immunotherapeutic agents, has been demonstrated to treat certain types of cancer alone or in combination with chemotherapeutic agents [3]. Although many anti-cancer treatments are available, drug resistance usually develops sooner or later, and some patients had poor or even no response to the treatment at the beginning. As a result, high cancer mortality remains, suggesting the urgent need of a large improvement in cancer treatment.

The tumor microenvironment is composed of the extracellular matrix and basement membrane, endothelial cells, cancer-associated fibroblasts, neuroendocrine cells, adipose cells, pericytes and tumor-infiltrating immune cells [4]. A tumor and its microenvironment interact constantly and influence each other. Such interactions begin at the very early phase 
of tumor formation, and continue during primary growth, local invasion, intravasation and establishment at the metastatic site. The role of the tumor microenvironment has been demonstrated to modulate the aggressiveness, motility, dissemination and colonization of cancer cells in distal organs in the past two decades [5]. Inflammation, including the leukotriene pathway, has been proposed as one of the mechanisms in tumor initiation, progression and metastasis [6]. Cancer-associated immune dysregulation is also a key contributor for tumor progression and metastasis.

By understanding the role of tumor microenvironment and cancer immunology in cancer progression, as well as the underlying detailed molecular mechanisms, we will have a better chance of developing novel diagnostic modalities and therapeutic agents for cancer diagnosis and treatment.

\section{Cysteinyl Leukotriene Pathway}

\subsection{Leukotrienes}

Leukotrienes were initially identified in the late 1970s, as a family of inflammatory lipid mediators synthesized from arachidonic acid (AA) in different cells, including mast cells, eosinophils, neutrophils, basophils and macrophages [7].

While the cell membrane encounters stimulation or injury, phospholipase A2 catalyzes the hydrolysis of AA from phospholipids of cell membrane (Figure 1). The stimulation could be inflammatory or immunologic processes, such as immediate hypersensitivity, platelet activating factor or calcium ionophore. The liberated free AA will then be dehydrated by 5-lipoxygenase (5-LO) in concert with 5-lipoxygenase-activating protein (FLAP) and become unstable epoxide leukotriene $\mathrm{A}_{4}\left(\mathrm{LTA}_{4}\right)[8,9]$. In the next step, the unstable epoxide $\mathrm{LTA}_{4}$ is converted by $\mathrm{LTA}_{4}$ hydrolase into leukotriene $\mathrm{B}_{4}\left(\mathrm{LTB}_{4}\right)$ and by leukotriene $\mathrm{C}_{4}\left(\mathrm{LTC}_{4}\right)$ synthase into $\mathrm{LTC}_{4}$ [10]. After transporting into the extracellular milieu, $\mathrm{LTC}_{4}$ will be converted to leukotriene $\mathrm{D}_{4}\left(\mathrm{LTD}_{4}\right)$ [11]. Finally, dipeptidase deprives $\mathrm{LTD}_{4}{ }^{\prime} \mathrm{s}$ glycine residue, turning $\mathrm{LTD}_{4}$ into leukotriene $\mathrm{E}_{4}\left(\mathrm{LTE}_{4}\right)$ [12].

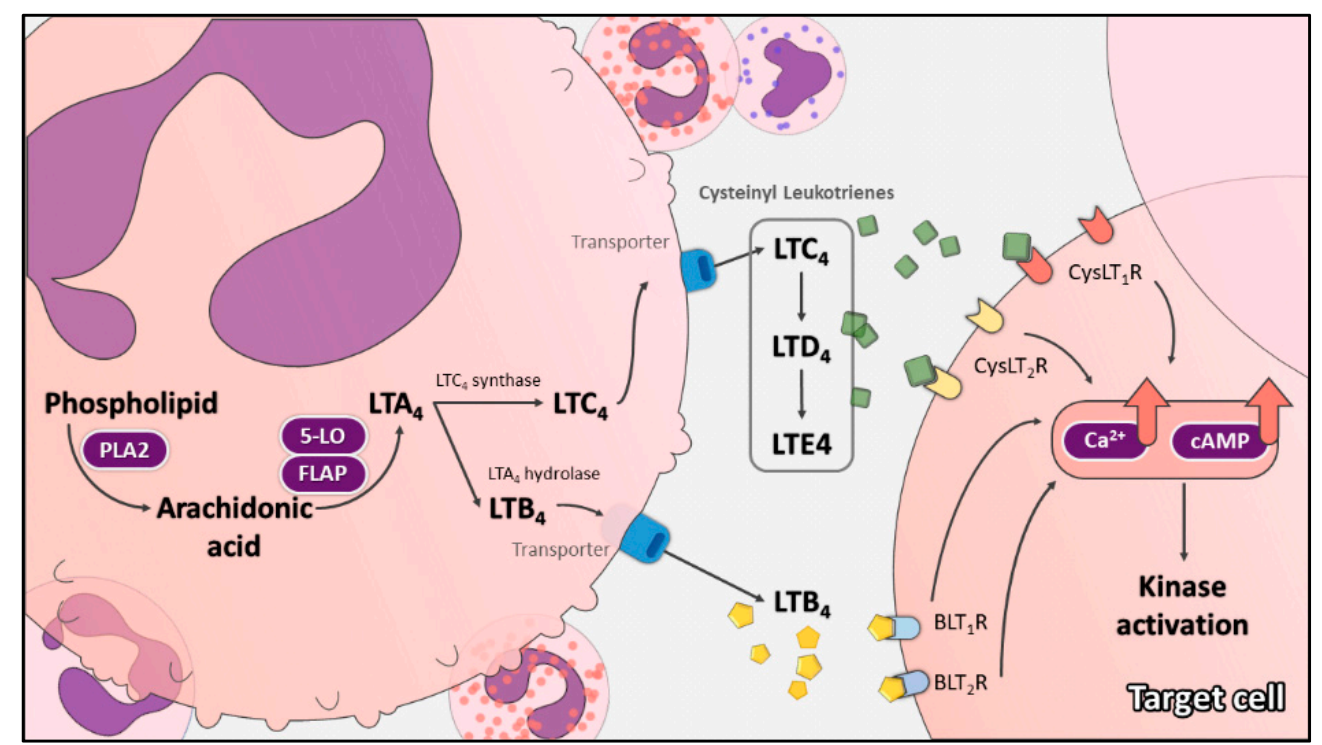

Figure 1. The cysteinyl leukotriene pathway. Leukotriene $\mathrm{A}_{4}\left(\mathrm{LTA}_{4}\right)$, originated from arachidonic acid, is converted into leukotriene $\mathrm{C}_{4}\left(\mathrm{LTC}_{4}\right)$ by $\mathrm{LTC}_{4}$ synthase. After transporting into the extracellular milieu, $\mathrm{LTC}_{4}$ is converted to leukotriene $\mathrm{D}_{4}\left(\mathrm{LTD}_{4}\right)$ and then leukotriene $\mathrm{E}_{4}\left(\mathrm{LTE}_{4}\right)$. The cysteinyl leukotrienes, including $\mathrm{LTC}_{4}, \mathrm{LTD}_{4}$ and $\mathrm{LTE}_{4}$, bind to cysteinyl leukotriene receptors, mainly $\mathrm{CysLT}_{1} \mathrm{R}$ and $\mathrm{CysLT}_{2} \mathrm{R}$, to activate signaling pathways in the target cells.

Due to lacking the peptide side chain of cysteinyl leukotrienes, $\mathrm{LTB}_{4}$ was not classified as cysteinyl leukotriene [13]. As a classical chemoattractant, $\mathrm{LTB}_{4}$ could trigger aggregation and adherence of leukocytes to the endothelium. Furthermore, it also regulates the immune 
responses associated with host-defense against infections. $\mathrm{LTB}_{4}$ is involved in many inflammatory diseases, including dermatitis, arthritis, nephritis and chronic obstructive pulmonary disease [10].

\subsection{Cysteinyl Leukotrienes}

The cysteinyl leukotrienes (CysLTs) include $\mathrm{LTC}_{4}, \mathrm{LTD}_{4}$ and $\mathrm{LTE}_{4}$ (Figure 1). Among them, $\mathrm{LTE}_{4}$ is the most stable, which can be measured in the urine. The urinary LTE $\mathrm{L}_{4}$ level could therefore be used as a marker of 'whole body' leukotriene synthesis [14]. LTC 4 is an 18-kDa membrane protein. It is a noncovalent homodimer. $\mathrm{Mg}^{2+}$ could augment the enzyme activity of $\mathrm{LTC}_{4}$; on the other hand, $\mathrm{Co}^{2+}$ and the function of FLAP inhibitor MK886 could inhibit it [15]. LTD $_{4}$ increased cytosolic calcium and activated the MAPK pathway in THP-1 cells, a human monocytic leukemia cell line [16,17]. Activation of PKC inhibited LTC $_{4}$ synthase activity and attenuates production of CysLTs in an eosinophilic sub-strain of human myeloid leukemia cell line HL-60 [18]. CysLTs are well-known for their role in inflammation, and have been reported to have pro-angiogenic activities [19-21].

There are three groups of cysteinyl leukotriene receptors (CysLTRs), including CysLT $_{1} \mathrm{R}$, CysLT $_{2} \mathrm{R}$ and $\mathrm{CysLT}_{3} \mathrm{R}$. The affinity of CysLTs to their receptors are different:

the affinity of CysLTs to CysLT 1 R: $\mathrm{LTD}_{4}>\mathrm{LTC}_{4}>>\mathrm{LTE}_{4}$; the affinity of CysLTs to CysLT 2 R: $\mathrm{LTD}_{4}=\mathrm{LTC}_{4}>>\mathrm{LTE}_{4}$; the affinity of CysLTs to CysLT 3 R: $\mathrm{LTC}_{4}>\mathrm{LTD}_{4}$ [22].

\section{3. $\mathrm{Cys}_{\mathrm{S}} \mathrm{T}_{1}$ Receptor $\left(\mathrm{CysLT}_{1} R\right)$}

$\mathrm{CysLT}_{1} \mathrm{R}$ distributes in various human tissues, including the respiratory system, peripheral blood leukocytes, gastrointestinal system and brain [7]. Smooth muscle cells, epithelial cells, interstitial lung macrophages and basophils accumulating in the airways of asthma patients could express CysLT $_{1} R[7,23,24]$. The expression of CysLT ${ }_{1} R$ could also be found in peripheral blood leukocytes, including monocytes, macrophages, eosinophils, pregranulocytic $\mathrm{CD} 4^{+}$cells, neutrophils and some B lymphocytes [7]. Tumors of the colon and brain also express CysLT $_{1} \mathrm{R}$ [22].

CysLT $_{1} \mathrm{R}$ is involved in several signal pathways. $\mathrm{LTD}_{4}$ is able to induce elevation of intracellular free $\mathrm{Ca}^{2+}$ concentration and phosphatidylinositol metabolism [25]. Via non-voltage gated channels, $\mathrm{LTD}_{4}$ could lead to constriction of the small bronchioles [26]. Activating CysLT $_{1} \mathrm{R}$ induces phosphorylation of mitogen-activated protein kinase (MAPK) through a $\mathrm{G}_{\mathrm{i} / \mathrm{o}}$-protein in mesangial cells, airway smooth muscle cells and human mast cells [22].

STAT-1 was demonstrated to be involved in the signal transduction mechanism of the CysLT $_{1}$ R; phosphorylation of STAT-1, through protein kinase C (PKC) and ERK1/2 activation, causes expression of ICAM-1 and increased eosinophil adhesion [24]. In studies of human asthma smooth muscle cells, $\mathrm{LTD}_{4}$ stimulation of $\mathrm{G}_{\mathrm{i} / \mathrm{o}}$-coupled $\mathrm{CysLT}_{1} \mathrm{Rs}$ leads to the transactivation of the epidermal growth factor receptors (EGFRs) through the intervention of PI3K and ROS, followed by the classical Ras-ERK1/2 signaling pathway. It could then control G1 progression and cell proliferation [23]. CysLT 1 R also plays an important role in Alzheimer's disease. In the study of primary cultured neurons, $\mathrm{LTD}_{4}$ was demonstrated to cause the production of $A \beta$ by enhancement of $\beta$ - or $\gamma$-secretase resulting from activating the $\mathrm{CysLT}_{1} \mathrm{R}$-mediated NF- $\mathrm{KB}$ signaling pathway [27].

\section{4. $\mathrm{CysLT}_{2}$ Receptor $\left(\mathrm{CysLT}_{2} R\right)$}

The mRNA of $\mathrm{CysLT}_{2} \mathrm{R}$ mRNA expression is high in the heart, interstitial macrophages of lung, brain, spleen, lymph nodes and peripheral blood [28]. The expression level of CysLT $_{2} \mathrm{R}$ mRNA is particularly high in the hypothalamus, thalamus, putamen, pituitary gland and medulla of brain. In the peripheral blood, eosinophils particularly express very high level of CysLT $_{2} \mathrm{R}$ [28]. On the cell surface of human umbilical vein endothelial cells, CysLT $_{2} \mathrm{R}$ is highly expressed and might be involved in leukotriene-dependent vascular reactions [29]. 
CysLT $_{2} \mathrm{R}$ induced microglia M1 polarization through activating the NF- $\mathrm{KB}$ pathway, and might promote inflammation and neuronal damage [30]. Aspirin-exacerbated respiratory disease is associated with idiosyncratic CysLT- and mast cells-driven reactions to aspirin. In aspirin-exacerbated respiratory disease, $\mathrm{CysLT}_{2} \mathrm{R}$ signaling on platelets could use RAGE/HMGB1 as a link to the downstream type 2 respiratory immunopathology and IL-33-dependent mast cell activation typical of aspirin-exacerbated respiratory disease [31].

\subsection{CysLT $_{3}$ Receptor (CysLT 3 R)}

$\mathrm{CysLT}_{3} \mathrm{R}$ has high-affinity for $\mathrm{LTE}_{4}$ [32]. CysLT $_{3} \mathrm{R}$ was demonstrated to be expressed on murine airway epithelial cells and to mediate goblet cell mucin release in response to exogenous $\mathrm{LTE}_{4}$ [33]. CysLT 3 R could also regulate the numbers of goblet cells in the nasal mucosa. The aeroallergen and $\mathrm{LTE}_{4}$-elicited $\mathrm{CysLT}_{3} \mathrm{R}$-dependent type 2 lung inflammation could be attenuated by blocking IL-25. Therefore, $\mathrm{CysLT}_{3} \mathrm{R}$ may have the potential to be a therapeutic target for inflammatory lung disease [34].

\subsection{Cysteinyl Leukotriene Pathway Antagonists}

In daily clinical practice, medications targeting the CysLT pathway are implicated in the treatment of asthma and allergic rhinitis. In patients with asthma, a chronic inflammatory lung disease characterized by airway hyperreactivity, CysLTs increased vascular permeability and smooth-muscle contraction, which are the causes of patients' symptoms [35]. The pharmacological mechanism of montelukast, zafirlukast and pranlukast in treating asthma is antagonism of $\mathrm{CysLT}_{1}$ Rs (Table 1). The other drug, zileuton, can be used for treating asthma by inhibiting 5-LO. However, the responses to these pharmacologic blockades remain heterogenous [35].

Table 1. Cysteinyl leukotriene pathway antagonists.

\begin{tabular}{|c|c|c|}
\hline Medication & Pharmacologic Effect & Remark \\
\hline Zileuton & 5-LO inhibitor & Clinically available * \\
\hline AA861 & 5-LO inhibitor & \\
\hline BU-4664L & 5-LO inhibitor & \\
\hline BWA4C & 5-LO inhibitor & \\
\hline ETH 615-139 & 5-LO inhibitor & \\
\hline MK591 & 5-LO inhibitor & \\
\hline MK886 & 5-LO inhibitor & \\
\hline Montelukast & Selective CysLT $_{1} \mathrm{R}$ antagonist & Clinically available * \\
\hline Zafirlukast & Selective CysLT $_{1} \mathrm{R}$ antagonist & Clinically available * \\
\hline Pranlukast & Selective CysLT $_{1} \mathrm{R}$ antagonist & Clinically available * \\
\hline MK571 & Selective $\mathrm{CysLT}_{1} \mathrm{R}$ antagonist & \\
\hline ZM198,615 & Selective $\mathrm{CysLT}_{1} \mathrm{R}$ antagonist & \\
\hline AP 100984 & Selective CysLT $_{2} R$ antagonist & \\
\hline BayCysLT $_{2}$ & Selective $\mathrm{CysLT}_{2} \mathrm{R}$ antagonist & \\
\hline HAMMI 3379 & Selective $\mathrm{CysLT}_{2} \mathrm{R}$ antagonist & \\
\hline Quininib & Selective CysLT ${ }_{1} \mathrm{R}\left(\right.$ and $\mathrm{CysLT}_{2} \mathrm{R}$ ) & \\
\hline 1,4-dihydroxy quininib & antagonist & \\
\hline
\end{tabular}

\section{In Vitro Studies about the Roles of Cysteinyl Leukotriene Pathway in Cancer}

Major findings of in vitro studies about the roles of the CysLT pathway in cancer are summarized in Table A1 in Appendix A.

\subsection{Hematologic Malignancies}

Studies about physiological roles of CysLTs in cancer cells have been initiated since 1980s, mainly in leukemia cells $[36,37]$. Increased LTC $_{4}$ production was noted in chronic myeloid leukemia (CML) [37,38]. Some early studies using leukemia cell lines further enriched our knowledge about the role of CysLTs in cell biology [16-18]. 
In line with clinical practice, tyrosine kinase inhibitors, such as imatinib, dasatinib and nilotinib, inhibited cell growth of CML cells, and montelukast further reduced cell proliferation in a dose-dependent manner as key proteins of the leukotriene pathway were expressed in these CML cells [39]. A subsequent study revealed that montelukast, through a CysLT $_{1}$ R-dependent pathway, induced apoptosis of CML cells by inducing Bax overexpression, cytochrome $C$ release, PARP-1 cleavage and caspase- 3 activation, which could be additive to the pro-apoptotic effect of imatinib; montelukast also altered Wnt $/ \beta$-catenin signaling, inducing phosphorylation of $\beta$-catenin and downregulating the downstream target c-myc [40].

In terms of chronic lymphocytic leukemia (CLL), two CLL cell lines (EHEB and MEC-1 cells) expressed high levels of $\mathrm{CysLT}_{1} \mathrm{R}$ and low level of $\mathrm{CysLT}_{2} \mathrm{R}$ [41]. $\mathrm{LTD}_{4}$ induced CysLT $_{1}$ R-mediated calcium fluxes, actin polymerization, chemotaxis and activation of MAPK pathway in CLL cells [41]. CysLT 1 R antagonists (MK571 and LY171883) reduced viability and increased apoptosis of CLL cells [41].

$\mathrm{CysLT}_{1} \mathrm{R}$ expression was demonstrated in human primary mediastinal B-cell lymphoma cell lines (Med-B1, Karpas-1106P); CysLTs induced a calcium signal in Med-B1 cells, which could be blocked by zafirlukast [42]. Some of the human Hodgkin lymphoma cell lines, including $\mathrm{L} 1236$ and $\mathrm{KMH} 2$ cells, expressed functional $\mathrm{CysLT}_{1} \mathrm{R}$, responding with a robust calcium signal upon $\mathrm{LTD}_{4}$ challenge, which could be blocked by zafirlukast [43].

\subsection{Colorectal Cancer}

The role of the CysLT pathway has been extensively studied in intestinal epithelium and associated tumors. The expression of $\mathrm{CysLT}_{1} \mathrm{R}$ was demonstrated in intestine 407 (Int 407), a non-transformed human embryonic intestinal epithelial cell line and two human colon cancer cell lines, Caco-2 and SW-480 [44].

Several studies have demonstrated the role of the CysLT pathway in cell survival of colorectal cancer cells. Overexpression of $\mathrm{CysLT}_{1} \mathrm{R}$ increased cell viability in Caco-2 cells [44]. A study using Int 407 found that $\mathrm{LTD}_{4}$ was capable of preventing apoptosis induced by NS-398, a COX-2 inhibitor [45]. Further study revealed that $\mathrm{LTD}_{4}$ not only reversed the apoptosis induced by COX-2 inhibition but also reduced the apoptotic potential by lowering the basal level of caspase 8 activation and truncated Bid generation [46]. LTD 4 enhanced proliferation via a distinct Ras-independent, PKC $\epsilon$-dependent activation of Erk$1 / 2$ and a parallel Ras-dependent signaling pathway [47]. A study using Int 407 and Caco-2 cells demonstrated that $\mathrm{LTD}_{4}$ induced upregulation of COX-2 and Bcl-2 through a pertussis toxin sensitive G-protein and MAPK pathway [48]. In both Int 407 and Caco-2 cells, $\mathrm{LTD}_{4}$ stimulation induced activation and nuclear translocation of cytosolic phospholipase $\mathrm{A}_{2} \alpha$, an important regulator of colon tumor growth, via a calcium-dependent mechanism involving activation of PKC and the MAPK pathway [49]. LTD $_{4}$ increased the level of free $\beta$-catenin in Int 407 cells; the increased free $\beta$-catenin translocated to the nucleus where it activated TCF/LEF transcription factors; the increased free $\beta$-catenin also translocated to the mitochondria where it associated to the antiapoptotic protein Bcl-2 [50]. Further studies showed that $\mathrm{LTD}_{4}$ increased mitochondrial metabolic activity and gene transcription and increased reactive oxygen species levels and subsequent activations of the p65 subunit of NF- $\kappa \mathrm{B}$, presumably through $\beta$-catenin accumulation in the mitochondria [51]. Collectively, these findings lend credence to the idea that the CysLT pathway potentially provides intrinsic oncogenic signals involving cell survival and anti-apoptosis.

Furthermore, $\mathrm{LTD}_{4}$ increased the motility of Int 407 cells via a PI3K/Rac signaling pathway [52]. $\mathrm{LTD}_{4}$ increased $\beta$-catenin level in colon cancer cells [53]. $\mathrm{LTD}_{4}$ induced nuclear translocation of $\beta$-catenin, upregulated $\beta$-catenin target genes and increased the proliferation and migration in HCT116 cells, but not in HT29 cells; the effect could be prevented by pretreatment with ZM198,615, a CysLT 1 R antagonist [53].

CysLT $_{1}$ Rs were found in the plasma membrane and outer nuclear membrane in both Int 407 and Caco-2 cells [54]. The colorectal carcinoma cell line, Caco-2 cells, appeared to have greater intracellular formation of CysLTs and more CysLT $_{1}$ Rs in both plasma 
membrane and outer nuclear membrane than the non-tumor cell line, Int 407 cells [54]. Another study found that the basal level of $\mathrm{CysLT}_{1} \mathrm{R}$ was higher in several colon cancer cell lines (HT-29, SW-480, Caco-2 and HCT-116) compared to Int 407 cells [55]. LTD 4 significantly increased CysLT $\mathrm{R}_{1} \mathrm{R}$ expression in Int 407 cells, but not in colon cancer cell lines; $\mathrm{LTD}_{4}$ induced upregulation of CysLT $2 \mathrm{R}$ in several colon cancer cell lines [55]. LTD ${ }_{4}$ could also induce nuclear translocation of $\mathrm{CysLT}_{1} \mathrm{Rs}$ from the plasma membrane to the nucleus in Int 407 cells, but not in Caco-2 cells [54].

A study using several intestinal epithelial cell lines found the autocrine pattern of endogenously produced CysLTs which mediated the survival and proliferation of intestinal epithelial cells via CysLT $_{1} R$ signaling [56]. MK571, a CysLT 1 R antagonist, induced apoptosis and dose-dependent proliferation inhibition in two non-tumor cell lines (Int 407 and IEC-6 cells), but only led to proliferation reduction without apoptosis in the tumor intestinal cell lines (Caco-2, SW480, HCT-116 and HT-29 cells); the presence of nuclear CysLT ${ }_{1}$ Rs in intestinal cancer cells, which are inaccessible to the receptor antagonist, might provide a clue to the finding [56]. In a study with HT-29 and SW-480, montelukast prevented $\mathrm{LTD}_{4}$-induced colony formation and disrupted colonospheres as well as downregulation of cancer stem cell markers (ALDH1 and DCLK1), suggesting the beneficial effect in minimizing cancer stem cells of $\mathrm{CysLT}_{1} \mathrm{R}$ inhibition [57]. In addition, 1,4-dihydroxy quininib reduced clonal formation and gene silencing of $\mathrm{CysLT}_{1} \mathrm{R}$ significantly reduced expression of angiogenic marker calpain-2, which further confirmed the importance of $\mathrm{CysLT}_{1} \mathrm{R}$ in cancer progression and angiogenesis [58].

The expression of low-affinity CysLT $2 R$, compared with $\mathrm{CysLT}_{1} R$, was higher in a nontumor cell line (Int 407) but was lower in two colon cancer cell lines (Caco-2 and SW480) [59]. Similar to $\mathrm{CysLT}_{1} \mathrm{R}, \mathrm{CysLT}_{2} \mathrm{R}$ was found to be located both at the plasma membrane and the nuclear membrane [59]. Although $\mathrm{CysLT}_{2} \mathrm{R}$ signaling had no effect on cell proliferation or apoptosis of Caco-2 cells, $\mathrm{LTC}_{4}$ increased the activity of alkaline phosphatase and aminopeptidase $\mathrm{N}$, suggesting the role of $\mathrm{CysLT}_{2} \mathrm{R}$ in cellular differentiation [59]. A subsequent study showed that IFN- $\alpha$ could upregulate CysLT 2 R in Caco-2 cells [60]. LTC $_{4}$ induced expression of mucin-2, and the effect could be blocked by AP 100984 (a specific $\mathrm{CysLT}_{2} \mathrm{R}$ antagonist) but not by montelukast (a specific $\mathrm{CysLT}_{1} \mathrm{R}$ antagonist) [60]. $\mathrm{CysLT}_{2} \mathrm{R}$ signaling was able to suppress cell migration induced by epidermal growth factor (EGF) signaling in Int 407 cells [60]. All-trans retinoic acid (ATRA) treatment increased $\mathrm{CysLT}_{2} \mathrm{R}$ expression without affecting CysLT 1 R level, and upregulated $\mathrm{LTC}_{4}$ synthase in SW480 cells; the effect was not observed in HCT-116 cells, which was ATRA-resistant [61]. ATRA did not affect cell proliferation or induce apoptosis of SW480 cells [61]. ATRA induced MUC-2 expression and alkaline phosphatase activity in SW480 cells, and AP 100984 reduced the effect [61].

\subsection{Pancreatic Cancer and Hepatoma}

A comprehensive study revealed $\mathrm{CysLT}_{1} \mathrm{R}$ expression in several pancreatic cancer cell lines (PA-TU-8988T, SUIT-2 and PANC1 cells, but not in MIAPaCa-2 cells); LTD $_{4}$ promoted the proliferation of pancreatic cancer cells, whereas treatment with montelukast caused cell cycle arrest at G0/G1 phase without inducing apoptosis [62].

In a recent study using human hepatoma cell lines, CysLT antagonists (pranlukast and montelukast) inhibited ADAM9 activity and upregulated level of membrane-bound MHC class I-related chain A (mMICA), which might facilitate natural killer cell-mediated cytotoxicity, suggesting the potential of using leukotriene receptor antagonists along with regorafenib in the treatment of hepatoma [63].

\subsection{Urological Malignancies}

Several studies have demonstrated $\mathrm{CysLT}_{1} \mathrm{R}$ expression in human cancer cells of renal cell carcinoma, bladder cancer, prostate cancer and testicular cancer [64-66]. Treatment with montelukast downregulated $\mathrm{CysLT}_{1} \mathrm{R}$ expression, reduced cell viability and induced early apoptosis in human prostate cancer cell lines (LNCaP, PC3, DU-145) [64,67], a human 
renal cell carcinoma cell line (Caki-1) [64,68], a human bladder cancer cell line (T24) [64,65] and a testicular cancer cell line (NEC-8) $[64,66]$. The effects were not observed in normal stromal prostate cell lines [67], normal proximal tubular endothelial cells (PRTEC) [68]. Montelukast also inhibited hypoxia-induced HIF-1 $\alpha$ activation in prostate cancer cells, but the effect was not shown by pranlukast and zafirlukast, suggesting this effect was not mediated by the CysLT 1 R pathway [69]. MK591, a 5-LO inhibitor developed to inhibit leukotriene biosynthesis, induced apoptosis in LNCaP cells [70]. Inhibition of 5-LO by MK886 completely blocked 5-HETE production, inducing massive apoptosis in both hormone-responsive (LNCaP) and hormone-nonresponsive (PC3) human prostate cancer cells [71].

\subsection{Breast Cancer}

$\mathrm{LTB}_{4}$ and $\mathrm{LTD}_{4}$ inhibited MCF-7 breast cancer cell growth, and a leukotriene antagonist (LY171883) and a 5-LO inhibitor (MK886) further lifted the inhibitory effect, suggesting that LT-receptors mediated the growth-inhibitory effect of $\mathrm{LTB}_{4}$ or $\mathrm{LTD}_{4}$ [72]. CysLTR antagonists, montelukast and zafirlukast reduced cell viability of MDAMB-231, a triplenegative breast cancer cell line, in a dose-dependent manner; zafirlukast mainly exerted its action on cell cycle, while montelukast mainly induced apoptosis [73].

Similar to the findings in colon cancer, activating CysLT 2 R signaling with $\mathrm{LTC}_{4}$ (preferentially binds to $\mathrm{CysLT}_{2} \mathrm{R}$, rather than $\mathrm{CysLT}_{1} \mathrm{R}$ ) did not affect cell proliferation or apoptosis of breast cancer cells but reduced cell migration [74].

\subsection{Lung Cancer}

Inhibition of 5-LO resulted in interruption of 5-LO-mediated growth factor signaling, resulting in significant growth reduction and enhanced apoptosis in a number of lung cancer cell lines [75]. Furthermore, 5-LO inhibitors (AA861 or ETH 615-139) and zafirlukast (a CysLT $_{1} \mathrm{R}$ antagonist) blocked the release of organic osmolytes (taurine, meAIB) and the concomitant cell volume restoration following hypoosmotic swelling of A549 cells; inhibition of 5-LO or $\mathrm{CysLT}_{1} \mathrm{R}$ did not affect caspase-3 activity during hypoxia [76].

Montelukast inhibited the viability/proliferation of several lung cancer cell lines (A549, H460, H1299, CL1-0 and CL1-5), and induced cell death via nuclear translocation of apoptosis-inducing factor (AIF) [77].

\subsection{Neurological Malignancies}

A study examined several neuroblastoma cell lines (SH-SY5Y, SK-N-BE2, SK-N-SH, SK-N-AS, SK-N-FI, SK-N-DZ, IMR-32) and found that all of them expressed 5-LO, CysLT 1 R and $\mathrm{CysLT}_{2} \mathrm{R}$ [78]. Neuroblastoma cells endogenously produced leukotrienes [78]. $\mathrm{LTD}_{4}$ significantly increased cell viability and proliferation of neuroblastoma cells, and montelukast induced cell cycle arrest and apoptosis [78].

Montelukast and zafirlukast inhibited proliferation and induced apoptosis of glioblastoma cells (A172 and U-87 MG cells) in a concentration-dependent manner; both medications decreased Bcl-2 expression without affecting Bax level [79]. Montelukast induced more apoptosis than zafirlukast in A172 cells, but not in U-87 MG cells; zafirlukast caused cell cycle arrest at G0/G1 phase by upregulating the expression of p53 and p21 and showed a greater antiproliferative effect than montelukast [79]. Montelukast and zafirlukast, but not zileuton, significantly inhibited migration and invasion of glioblastoma cells, as well as inhibiting the expression and activities of MMP-2 and MMP-9 in glioblastoma cells and primary human astrocytes, suggesting the important role of $\mathrm{CysLT}_{1} \mathrm{R}$ in migration and invasion of glioblastoma [80].

\subsection{Other Malignancies}

Uveal melanoma cell lines derived from primary (Mel285, Mel270) and metastatic (OMM2.5) uveal melanoma expressed $\mathrm{CysLT}_{1} \mathrm{R}$ and $\mathrm{CysLT}_{2} \mathrm{R}$ [81]. Montelukast, quininib and 1,4-dihydroxy quininib significantly inhibited uveal melanoma cells in a time- and 
dose-dependent manner, whereas a CysLT $_{2}$-selective antagonist, HAMI 3379, did not show growth inhibition effect [81]. Quininib significantly inhibited long-term proliferation, altered the cancer secretome of inflammatory and angiogenic factors and inhibited oxidative phosphorylation [81].

$\mathrm{LTC}_{4}$ mediated the second wave of Rac1 activation and cell migration; treatment with 5-LO inhibitors (AA861 and BU-4664L) or CysLT 1 R antagonists (MK571 and montelukast), as well as knockdown of $\mathrm{CysLT}_{1} \mathrm{R}$, suppressed cell migration of A431 cells, an epidermoid carcinoma cell line, through downregulating EGF-induced expression of T cell lymphoma invasion and metastasis-inducing protein 1 (Tiam1) [82].

\subsection{Drug Resistance and Cysteinyl Leukotriene Pathway}

The $\mathrm{LTD}_{4}$ receptor has been highly associated with multidrug resistance protein (MRP), a membrane transporter of multiple anticancer drugs. MK571, a CysLT 1 R antagonist, modulated MRP-associated multidrug resistance in HL60/AR and GLC4/ADR cells, MRP-overexpressing multidrug resistant human leukemia and human small cell lung cancer cell lines, respectively, in a dose-dependent manner [83]. Similarly, increased expression of multidrug-resistance-associated protein 1 (MRP1) was observed in multidrug resistant phenotype of prostate cancer, and adding non-toxic doses of MK571, zafirlukast or buthionine sulfoximine significantly increased the sensitivity of the MDR models to cytotoxic drugs [84].

ONO-1078, a peptide $\mathrm{LTD}_{4}$ receptor antagonist, inhibited the transporting activity of MRP and increased vincristine uptake, resulting in increased sensitivity to vincristine of multidrug-resistant CV60 and its parental drug-sensitive KB-3-1 cell line [85]. Similarly, ONO-1078 enhanced the sensitivity of lung cancer NCI-H520 cells to several chemotherapeutic agents, including vincristine, doxorubicin and etoposide, through inhibiting the function of MRP [86].

To investigate the role of $\mathrm{CysLT}_{1} \mathrm{R}$ in chemoresistance, a study established 5-FUresistant colon cancer cell lines by culturing with increasing concentration of 5-FU over a period of 6-8 months [87]. The 5-FU-resistant colon cancer cell lines expressed increased CysLT $_{1} \mathrm{R}$, which regulated 5 -FU resistance via $\beta$-catenin activation and promoted 5-FUresistance-derived stemness [87]. Montelukast restricted the motility of 5-FU-resistant colon cancer cells, sensitized them to 5-FU and decreased 5-FU-resistance-derived stemness, suggesting that inhibition of $\mathrm{CysLT}_{1} \mathrm{R}$ signaling with montelukast might reverse drug resistance of colon cancer [87].

\section{Animal Studies about the Roles of Cysteinyl Leukotriene Pathway in Cancer}

Major findings of animal studies about the roles of the CysLT pathway in cancer are summarized in Table A2 in Appendix A.

\subsection{The Role of Vascular Permeability Mediated by Cysteinyl Leukotrienes}

CysLTs may modulate vascular permeability, and therefore may affect drug delivery or tumor metastasis. An animal study using a rat C6 glioma model showed that $\mathrm{LTE}_{4}$ selectively opened the blood-tumor barrier and increased the tumor uptake of intravenously injected methotrexate [88].

In contrast, CysLTR antagonists may inhibit tumor metastasis by inhibiting capillary permeability. An animal study using transplantable rat colon adenocarcinoma RCN9 cells implanted via the cisterna magna of male Fisher rats showed that pranlukast, but not montelukast, could inhibit tumor cell migration through brain capillary [89]. Using Lewis lung carcinoma metastasis model in mice, the effect of both pranlukast and montelukast on inhibiting tumor cell migration through peripheral capillary was demonstrated [89].

A study using male C57BL/6 mice, including wild type, Cysltr $1^{-/-}$and Cysltr $2^{-/-}$, implanted with Matrigel plugs or subcutaneously injected with Lewis lung carcinoma cells demonstrated the important role of $\mathrm{CysLT}_{2} \mathrm{R}$ in regulating tumor angiogenesis, metastasis and endothelial cell dysregulation [90]. CysLT $_{2}$ R-regulated angiogenesis was shown in 
isolated mouse endothelial cells and in Matrigel implants [90]. The growth and metastases of implanted Lewis lung carcinoma cells were significantly reduced in $C y s L T_{2} R$-null mice, compared with wild-type or $C y s L T_{1} R$-null mice. In wild-type mice subcutaneously implanted with Lewis lung carcinoma cells, the expression of $\operatorname{CysLT}_{2} R$, but not $\mathrm{CysLT}_{1} \mathrm{R}$, was increased in tumor vasculature, while BayCysLT 2 (a selective $\mathrm{CysLT}_{2} \mathrm{R}$ antagonist), but not MK571 (a CysLT 1 R antagonist), reduced tumor growth, angiogenesis and lung metastasis of tumor cells [90].

\subsection{Colorectal Cancer}

The role of CysLTs in colon cancer have been investigated in several studies using a xenograft model of nude mouse subcutaneously injected with human colon cancer cells. $\mathrm{LTD}_{4}$ promoted cancer-initiating cells in initiating tumor growth by allowing immunomodulation of the tumor microenvironment [91]. The important role of $\mathrm{CysLT}_{1} \mathrm{R}$ in colon tumorigenesis was shown in a study using a colitis-associated colon cancer mice model induced by azoxymethane/dextran sulfate sodium, showing higher relative body weight, reduction in inflammation and polyps with lower-grade dysplasia and decreased nuclear expression of $\beta$-catenin and COX-2 in mice with global disruption of CYSLTR1 gene expression [92]. In studies using a xenograft model, $\mathrm{CysLT}_{1} \mathrm{R}$ antagonists (montelukast and ZM198,615) inhibited proliferation and induced apoptosis of tumor cells, resulting in reduced size of the inoculated tumor [57,93]. Montelukast also significantly decreased amounts of cancer-stem cells, as well as macrophage infiltration and decreased expression of ALDH1A1, DCLK1 and BCL2 in the tumor tissue [57]. As CysLTs might involve in angiogenesis, 1,4-dihydroxy quininib significantly reduced tumor volume and the expression of angiogenic marker calpain-2 [58].

\subsection{Pancreatic Cancer}

The chemo-preventive effect and therapeutic potential of montelukast on pancreatic cancer was studied with a Syrian golden hamster model, using N-nitrosobis (2-oxopropyl) amine (BOP) to induce pancreatic ductal carcinomas, which were shown to be similar to those in humans morphologically and molecularly; montelukast suppressed pancreatic carcinogenesis by suppressing cell proliferation via the $\mathrm{LTD}_{4}-\mathrm{CysLT}_{1} \mathrm{R}$ axis [62].

\subsection{Lung Cancer}

The effects of leukotriene pathway inhibitors (zafirlukast, MK886 and Zileuton) on preventing lung cancer were investigated with a mice model of lung tumors induced by vinyl carbamate injection; leukotriene pathway inhibitors (zafirlukast, MK886 and zileuton) prevented lung tumor formation and slowed the growth and progression of adenomas to carcinoma [94]. A later study, using an orthotopic immunocompetent mouse model of lung cancer with Lewis lung carcinoma cells injected into lungs of syngeneic mice, found increased production of leukotrienes $\left(\mathrm{LTB}_{4}, \mathrm{LTC}_{4}, \mathrm{LTD}_{4}\right.$ and $\left.\mathrm{LTE}_{4}\right)$, in dependent on cytosolic phospholipase $\mathrm{A}_{2}$, in the tumor microenvironment [95]. Our study using mice with Lewis lung carcinoma cells injected subcutaneously (to monitor the tumor growth on a daily basis) showed that montelukast significantly hampered the tumor growth, and the tumor tissue of the montelukast group showed markedly decreased Ki-67 expression and markedly increased terminal deoxynucleotidyl transferase dUTP nick end labeling (TUNEL)-positive cells [77].

\subsection{Neurological Malignancies}

An animal study using experimental brain tumor of intracerebral C6 glioma in a Sprague-Dawley rat model found that pretreatment with $\mathrm{LTC}_{4}$ significantly extends survival in rats treated with cisplatin [96]. 


\section{Clinical Studies about the Roles of Cysteinyl Leukotriene Pathway in Cancer}

Major findings of clinical studies about the roles of the CysLT pathway in cancer are summarized in Table A3 in Appendix A.

\subsection{Hematological Malignancies}

A study analyzing blood samples from 17 CML patients in the chronic phase and 15 healthy medication-free volunteers found that mature CML CD16 (+) neutrophils had aberrantly increased expression of $\mathrm{LTC}_{4}$ synthase, which might be responsible for stimulating the proliferation of human bone marrow-derived myeloid progenitor cells [97]. A subsequent study showed that urinary excretion of $\mathrm{LTE}_{4}$ was significantly higher in CML patients than healthy controls, supporting the increased $\mathrm{LTC}_{4}$ synthase activity in CML patients; they further found that neutrophilic LTC $_{4}$ synthase expression and activity were markedly elevated and were normalized with imatinib mesylate treatment [98]. A study using multiplex single cell polymerase chain reaction analyzed the expression of the mediators of the leukotriene pathway in bone marrow BCR-ABL ${ }^{+} \mathrm{CD} 34^{+} \mathrm{CD} 38^{-}$cells at diagnosis found the majority of cells expressed $\mathrm{CysLT}_{1} \mathrm{R}$ and $\mathrm{CysLT}_{2} \mathrm{R}$, but not ALOX5; treatment with zileuton or montelukast failed to suppress cell growth, suggesting that targeting the CysLT pathway may not be a promising strategy to eradicate leukemia stem cells in CML patients [99].

The lymph node biopsy specimens from 57 non-Hodgkin lymphoma patients were assessed using immunohistochemical staining, and it was found that primary mediastinal B-cell lymphoma was the only type showing CysLT $_{1} R$ expression in tumor cells, while other types of lymphoma included in the study showed no CysLT ${ }_{1} R$ expression [42]. The same study group further assessed biopsy specimens from 29 Hodgkin lymphoma patients with immunohistochemical studies and assessed the micro-dissected Hodgkin Reed-Sternberg cells with microarray analysis, showing that $\mathrm{CysLT}_{1} \mathrm{R}$ was expressed by primary Hodgkin Reed-Sternberg cells, which were surrounded by CysLT-producing eosinophils, macrophages and mast cells; the findings might suggest that CysLTs were important mediators in the pathogenesis of Hodgkin lymphoma, contributing to the aberrant cytokine network [43].

\subsection{Colorectal Cancer}

Several studies have analyzed tissue samples from colorectal cancer patients with immunohistochemical staining, in situ hybridization and tissue microarrays, showing higher $\mathrm{CysLT}_{1} \mathrm{R}$ and 5-LO expression, particular in the nuclei, in the cancer tissues than in normal colon tissues [54]. Nuclear accumulation of $\mathrm{CysLT}_{1} \mathrm{R}$ was strongly correlated with stronger staining of proliferative marker Ki-67 [54]. Higher expression of CysLT 1 R, particularly in the nucleus, was associated with a poorer prognosis [44,100], whereas higher nuclear expression of $\mathrm{CysLT}_{2} \mathrm{R}$ was associated with an earlier stage and better prognosis $[59,100]$. Aggressive tumors generally expressed less $\mathrm{CysLT}_{2} \mathrm{R}$ and IFN- $\alpha$ receptor and more EGFR, with a negative correlation between $\mathrm{CysLT}_{2} \mathrm{R}$ and EGFR expression, suggesting a potential protective role of $\mathrm{CysLT}_{2} \mathrm{R}$ against tumor progression [60]. In addition, 1,4-dihydroxy quininib significantly decreased the secretion of both angiogenic factor TIE-2 and adhesion molecule VCAM-1 in human ex vivo colorectal cancer tumor explants [58].

\subsection{Esophageal Cancer and Gastric Cancer}

A study assessed esophageal biopsy specimens with specific enzyme immunoassays found higher expression levels of $\mathrm{LTB}_{4}$ and CysLTs in esophageal adenocarcinoma tissue compared to Barrett's metaplasia and control tissues [101]. However, another study analyzing esophageal biopsy samples with immunohistochemistry and quantitative reverse transcription-polymerase chain reaction showed significantly lower expression levels of $\mathrm{CysLT}_{1} \mathrm{R}$ and $\mathrm{CysLT}_{2} \mathrm{R}$ in esophageal cancer tissues than in control squamous epithelium [102]. 
Assessing with immunohistochemistry, gastric cancer tissue showed significantly increased immunoreactive score of $\mathrm{CysLT}_{1} \mathrm{R}$ than tumor-free gastric mucosa; the intestinal type had more CysLT $_{1} R$ and CysLT $_{2} R$ expression than the diffuse type [103].

\subsection{Pancreatic Cancer and Hepatoma}

In a study enrolling 92 hepatocellular carcinoma patients and 20 healthy control subjects, remarkably higher circulating $\mathrm{LTD}_{4}$ level was noted in patients of hepatocellular carcinoma, particular in those with chronic hepatitis B infection or metastasis [104].

Immunohistochemical analyses of 108 pancreatic ductal adenocarcinoma tissues revealed that high $\mathrm{CysLT}_{1} \mathrm{R}$ expression was associated with worse overall survival [62].

\subsection{Urological Malignancies}

Strong CysLT $_{1} \mathrm{R}$ expression was noted in several urological cancer samples, including renal cell carcinoma [64,68], bladder cancer (transitional cell carcinoma) $[64,65]$, prostate cancer and prostatic intraepithelial neoplasia $[64,67]$ and testicular cancer (including seminoma, embryonal carcinoma, yolk sac tumors, choriocarcinoma and teratoma) $[64,66]$, than in the corresponding normal tissue, and more extensive and intense expression was noted in cancer with a higher grade or an advanced stage. Very weak $\mathrm{CysLT}_{1} \mathrm{R}$ expression was observed in relatively normal tissues (normal kidney tissue, normal bladder tissue, benign prostatic hyperplasia, normal prostate tissue and normal testis tissue) [64].

\subsection{Breast Cancer}

A study investigating 144 breast cancer specimens with tissue microarray and immunohistochemistry found that breast cancers with higher $\mathrm{CysLT}_{1} \mathrm{R}$ and lower $\mathrm{CysLT}_{2} \mathrm{R}$ expression levels were associated with higher histological grade and worse overall survival [74].

\subsection{Other Malignancies}

CysLT $_{1} \mathrm{R}$ staining was evident in neuroblastoma surgical specimens and the adjacent vasculature, suggesting a potential treatment target [78].

A study assessing data of 80 primary uveal melanoma samples in The Cancer Genome Atlas (TCGA) showed that higher expression of CYSLTR1 and CYSLTR2 genes were significantly associated with poorer disease-free survival and overall survival [81]. However, the study group also examined the tissue from 52 patients of primary uveal melanoma using tissue microarray and only found poorer overall survival in those with higher $\mathrm{CysLT}_{1} \mathrm{R}$ expression, whereas CysLT $_{2} \mathrm{R}$ expression was not associated with survival [81].

\subsection{Chemopreventive Effects of Cysteinyl Leukotriene Inhibition}

A large nationwide retrospective cohort study using the Taiwan National Health Insurance Research Database investigated the effect of CysLTR antagonists (LTRAs), including montelukast and zafirlukast, in reducing cancer incidence in asthma patients [105]. Comparing 4185 LTRA users with 20,925 LTRA non-users, we found that using LTRA decreased cancer risk in a dose-dependent manner, and the chemo-preventive effect of LTRA was markedly observed in terms of lung, colorectal, liver and breast cancer [105]. Another national retrospective cohort study used data from the Department of Veteran Affairs to investigate the association between leukotriene inhibition and lung cancer incidence among U.S. Veterans with asthma [106]. The researchers found that 23,730 patients with leukotriene pathway inhibiting medication (montelukast, zafirlukast, or zileuton) exposure, compared with 534,736 patients without exposure, had significantly reduced risk of lung cancer [106].

\section{Future Perspectives}

In summary, inflammation plays important roles in tumor initiation, progression and metastasis [6], and the role of the CysLT pathway in cancer has been demonstrated in several 
cancers using different approaches. Increased 5-LO expression and downstream CysLT pathway have been recognized as inflammation to shape the tumor microenvironment and are associated with cancer proliferation, migration and invasion.

Serial change in the expression level of $\mathrm{CysLT}_{1} \mathrm{R}$ within the spectrum from normal tissue to low-grade and then advanced malignancies has been documented in several cancers. For example, very weak $\mathrm{CysLT}_{1} \mathrm{R}$ expression was observed in relatively normal tissues or benign lesions of urological organs [64]. In contrast, strong $\mathrm{CysLT}_{1} \mathrm{R}$ expression was noted in several urological cancer samples, with higher expression associated with a higher tumor grade or an advanced stage [64-68]. Similarly, higher $\mathrm{CysLT}_{1} \mathrm{R}$ and 5-LO expression was noted in colon cancer tissues than in normal colon tissues, with higher expression level of $\mathrm{CysLT}_{1} \mathrm{R}$ associated with higher tumor Ki-67 level and poorer prognosis $[44,54,100]$. The role of $\mathrm{CysLT}_{1} \mathrm{R}$ in colon tumorigenesis was demonstrated in a study using a colitisassociated colon cancer mice model, showing polyps with lower-grade dysplasia in mice with disruption of CYSLTR1 expression [92]. These findings demonstrated the important role of the CysLT pathway in carcinogenesis and tumor progression.

While the findings still appear somewhat heterogenous, further studies are warranted to clarify the role of the CysLT pathway in cancer biology, including cancer cells and their microenvironment, of different cancers. In our opinion, the following aspects require further investigation: (1) the roles of CysLTs and CysLTRs in proliferation, stemness, invasion and migration of cancer cells, as well as their secretomes and interactions with other cells in the tumor microenvironment; (2) the roles of CysLTs and CysLTRs in the cells in tumor microenvironment, particularly tumor-associated immune cells, which establish a cancerpromoting milieu; (3) the effects of CysLT inhibition, particularly CysLTR antagonists, in chemoprevention; and (4) the effects of CysLT inhibition, particularly CysLTR antagonists, as adjunct for the currently available standard anti-cancer treatment modalities. With more understanding about the role of the CysLT pathway in cancer, we will have better chance to provide precision care, including diagnostic and therapeutic approaches, for cancer patients.

Author Contributions: Conceptualization, M.-J.T. and J.-Y.H.; data curation, M.-J.T., W.-A.C. and C.-H.C. (Cheng-Hao Chuang); writing-original draft preparation, M.-J.T., W.-A.C. and J.-Y.H.; writing-review and editing, K.-L.W., C.-H.C. (Chih-Hung Cheng), Y.-L.H. and C.-C.S. All authors have read and agreed to the published version of the manuscript.

Funding: This research was funded by the Ministry of Science and Technology (grant number: MOST-104-2314-B-037-034-MY3 and MOST-108-2314-B-037-097-MY3), Kaohsiung Municipal Ta-Tung Hospital (kmtth-109-R012), and Kaohsiung Medical University Hospital (KMUH108-8R15).

Institutional Review Board Statement: Not applicable.

Informed Consent Statement: Not applicable.

Data Availability Statement: Not applicable.

Conflicts of Interest: The authors declare no conflict of interest related to this article. 


\section{Appendix A}

Table A1. Selected in vitro studies investigating the cysteinyl leukotriene pathway in cancer.

\begin{tabular}{ll}
\hline \multicolumn{1}{c}{ Author, Year } & \multicolumn{1}{c}{ Cancer Cells } \\
\hline Hematologic malignancies & \\
\cline { 1 - 2 } Stenke L, 1988 [37] & chronic myelogenous leukemia cell \\
\hline Stenke L, 1990 [38] & chronic myelogenous leukemia cell \\
\hline Chan CC, 1994 [16] & THP-1, a human monocytic leukemia cell line \\
\hline Hoshino M, 1998 [17] & THP-1, a human monocytic leukemia cell line \\
\hline & $\begin{array}{l}\text { chronic myeloid leukemia (CML) cell lines } \\
\text { (K562, KCL22, KU812), primary CD34 + } \\
\text { blood cells from two CML patients, human } \\
\text { colon carcinoma cell lung (HCT-116), lung } \\
\text { fibroblast cell line (WI-38) }\end{array}$ \\
\hline
\end{tabular}

Zovko A, 2018 [40] chronic myeloid leukemia cell lines (K562 and JURL-MK1)
Increased $\mathrm{LTC}_{4}$ synthase activity with increased $\mathrm{LTC}_{4}$ production in chronic myelogenous leukemia cells.

Increased $\mathrm{LTC}_{4}$, rather than $\mathrm{LTB}_{4}$, producing capacity in patients of chronic myelogenous leukemia.

$\mathrm{LTD}_{4}$ induced increased cytosolic calcium in THP-1 cells.

$\mathrm{LTD}_{4}$ activated the MAPK pathway.

Montelukast and BWA4C (a 5-LO inhibitor) reduced cell proliferation of CML cells in a dose dependent manner.

Montelukast, through a CysLT $\mathrm{C}_{1}$-dependent pathway, induced apoptosis of CML cells by inducing Bax overexpression, cytochrome $\mathrm{c}$ release, PARP-1 cleavage, and caspase- 3 activation, as well as altered $\mathrm{Wnt} / \beta$-catenin signaling.

EHEB and MEC-1 cells expressed high levels of CysLT $_{1} \mathrm{R}$ and low level of CysLT 2 R. LTD $_{4}$ induced $\mathrm{CysLT}_{1} \mathrm{R}$-mediated calcium fluxes, actin polymerization, chemotaxis and activation of MAPK pathway in chronic lymphocytic leukemia (CLL) cells. CysLT $_{1} R$ antagonists (MK571 and LY171883) reduced viability and increased apoptosis of CLL cells.

chronic lymphocytic leukemia cell lines (EHEB, MEC-1); primary chronic

Drost AC, 2012 [41] lymphocytic leukemia cells from 54 patients CD19 + (B cells) and CD19-cells from 8 healthy individuals human primary mediastinal B-cell

Schain F, 2008 [42] lymphoma cell lines (Med-B1, Karpas-1106P) and a Hodgkin lymphoma cell line (L1236)

Schain F, 2008 [43]

human Hodgkin lymphoma cell line cell lines (L1236, HDLM2, KMH2, L428, L591)

Med-B1, Karpas-1106P and L1236 cells expressed CysLT 1 R. LTC $_{4}$ and $\mathrm{LTD}_{4}$ induced a calcium signal in Med-B1 cells, which could be blocked by zafirlukast.

L1236 and KMH2 cells expressed functional CysLT $_{1} \mathrm{R}$, responding with a robust calcium signal upon $\mathrm{LTD}_{4}$ challenge, which could be blocked by zafirlukast.

\section{Colorectal cancer}

Ohd JF, 2003 [44]

Int 407 and two human colon cancer cell lines (Caco-2 and SW-480)

Nielsen CK, 2003 [45]

Intestine 407 (Int 407), a human embryonic intestinal epithelial cell line

Intestine 407 (Int 407), a human embryonic intestinal epithelial cell line
Int 407, Caco- 2 and SW-480 expressed CysLT 1 R. The viability of Caco- 2 cells increased with overexpression of $\mathrm{CysLT}_{1} \mathrm{R}$.

$\mathrm{LTD}_{4}$ prevented apoptosis of Int 407 cells induced by NS-398, a COX-2 inhibitor.

$\mathrm{LTD}_{4}$ prevented apoptosis of Int 407 cells induced by NS-398, a COX-2 inhibitor. $\mathrm{LTD}_{4}$ also reduced the apoptotic potential by preventing caspase 8 activation and Bid cleavage. 
Table A1. Cont.

\begin{tabular}{cl}
\hline \multicolumn{1}{c}{ Author, Year } & \multicolumn{1}{c}{ Cancer Cells } \\
\hline Paruchuri S, 2002 [47] & $\begin{array}{l}\text { Intestine } 407 \text { (Int 407), a human embryonic } \\
\text { intestinal epithelial cell line }\end{array}$ \\
\hline Wikström K, 2003 [48] & $\begin{array}{l}\text { a human embryonic intestinal epithelial cell } \\
\text { line (Int 407) and a human colorectal } \\
\text { carcinoma cell line (Caco-2) }\end{array}$ \\
\hline
\end{tabular}

Parhamifar L, 2005 [49]

a human embryonic intestinal epithelial cell line (Int 407) and a human colorectal carcinoma cell line (Caco-2)

Mezhybovska M, 2006 [50]

Intestine 407 (Int 407), a human embryonic intestinal epithelial cell line
Major Findings

LTD $_{4}$ enhance proliferation of Int 407 cells via two distinct signaling pathways (a Ras-independent and a Ras-dependent).

$\mathrm{LTD}_{4}$ upregulated COX-2 and Bcl-2 through a pertussis toxin sensitive G-protein and MAPK pathway in Int 407 and Caco-2 cells.

$\mathrm{LTD}_{4}$ stimulation induced cytosolic phospholipase $\mathrm{A} 2 \alpha$ activation and nuclear translocation via a calcium-dependent mechanism involving activation of PKC and the MAPK pathway in both Int 407 and Caco-2 cells.

$\mathrm{LTD}_{4}$ induced $\beta$-catenin signaling in Int 407 cells, which activated TCF/LEF transcription factors in the nucleus and increased the association between $\beta$-catenin with Bcl-2 in the mitochondria.

$\mathrm{LTD}_{4}$ increased mitochondrial metabolic activity and gene transcription and increased reactive oxygen species levels and subsequent activations of the p65 subunit of NF- $\mathrm{kB}$, presumably through $\beta$-catenin accumulation in the mitochondria. line (Int 407) and a human colorecta carcinoma cell line (Caco-2)

LTD $_{4}$ trigger a motile response of Int 407 cells Intestine 407 (Int 407), a human embryonic intestinal epithelial cell line via a PI3K/Rac signaling pathway.

$\mathrm{LTD}_{4}$ increased $\beta$-catenin level in colon cancer cells. In HCT116 cells but not in HT29 cells, $\mathrm{LTD}_{4}$ induced nuclear translocation of $\beta$-catenin, upregulated $\beta$-catenin target genes, and enhanced proliferation and migration; the effect could be prevented by pretreatment with ZM198,615, a CysLT 1 R antagonist.

$\mathrm{CysLT}_{1}$ Rs were found in the outer nuclear membrane in Int 407 and Ca-co- 2 cells. $\mathrm{LTD}_{4}$ induced nuclear translocation of the $\mathrm{CysLT}_{1} \mathrm{Rs}$ from the plasma membrane to the nucleus in Int 407 cells.

a human embryonic intestinal epithelial cell line (Int 407) and a human colorectal carcinoma cell line (Caco-2)

The basal level of CysLT $_{1} \mathrm{R}$ was higher in colon cancer cells compared to Int 407 cells. LTD $_{4}$ significantly increased $\mathrm{CysLT}_{1} \mathrm{R}$ expression in Int 407 cells, but not in colon cancer cell lines; $\mathrm{LTD}_{4}$ induced upregulation of $\mathrm{CysLT}_{2} \mathrm{R}$ in colon cancer cell lines.

Constitutive $\mathrm{CysLT}_{1} \mathrm{R}$ signaling, which was maintained in an autocrine pattern, mediated both survival and proliferation of intestinal cells. A CysLT 1 R antagonist (MK571) induced apoptosis in non-tumor intestinal cells, but not in tumor-derived intestinal cell lines.

Montelukast prevented $\mathrm{LTD}_{4}$-induced colony formation and disrupted colonospheres, as well as downregulation of cancer stem cell markers (ALDH1 and DCLK1). 
Table A1. Cont.

\begin{tabular}{cl}
\hline Author, Year & \multicolumn{1}{c}{ Cancer Cells } \\
\hline & \\
Magnusson C, 2007 [59] & $\begin{array}{l}\text { Int 407 and two human colon cancer cell lines } \\
\text { (Caco-2 and SW-480) }\end{array}$
\end{tabular}

(Caco-2 and SW-480)

The expression of $\mathrm{CysLT}_{2} \mathrm{R}$, compared with CysLT $_{1} R$, was higher in Int 407 but lower in two colon cancer cell lines (Caco-2 and SW480).

CysLT $_{2} \mathrm{R}$ was found to be located both at the plasma membrane and the nuclear membrane. $\mathrm{CysLT}_{2} \mathrm{R}$ signaling led to terminal differentiation of Caco-2 cells but had no effect on cell proliferation or apoptosis.

IFN- $\alpha$ could upregulate CysLT $_{2} R$ in Caco- 2 cells. $\mathrm{LTC}_{4}$ induced expression mucin-2, and the effect could be blocked by AP 100984 (a

Magnusson C, 2011 [60]

Int 407 and 2 colon cancer cell lines (Caco-2, SW-480) specific $\mathrm{CysLT}_{2} \mathrm{R}$ antagonist) but not by montelukast (a specific CysLT $\mathrm{C}_{1} \mathrm{R}$ antagonist). CysLT $_{2} \mathrm{R}$ signaling was able to suppress cell migration induced by EGF signaling in Int 407 cells.

All-trans retinoic acid (ATRA) treatment increased $\mathrm{CysLT}_{2} \mathrm{R}$ expression without affecting $\mathrm{CysLT}_{1} \mathrm{R}$ level, and upregulated $\mathrm{LTC}_{4}$ synthase in SW480 cells; the effect was not observed in HCT-116 cells. ATRA did not affect cell proliferation or induce apoptosis of SW480 cells. ATRA induced MUC-2 expression and alkaline phosphatase activity in SW480 cells, and a $\mathrm{CysLT}_{2} \mathrm{R}$ antagonist (AP 100984) reduced the effect.

1,4-dihydroxy quininib reduced clonal formation of HT29-Luc2. Gene silencing of CysLT $_{1}$ R in HT29-Luc2 cells significantly reduced expression of angiogenic marker calpain-2.

Pancreatic cancer and hepatoma

Kachi K, 2021 [62]

human pancreatic cancer cell lines

(PA-TU-8988T, MIAPaCa-2, SUIT-2, PANC1)
CysLT $_{1} \mathrm{R}$ was expressed in PA-TU-8988T, SUIT-2 and PANC1 cells, but not in MIAPaCa-2 cells. LTD $_{4}$ promoted pancreatic cancer cell proliferation, whereas treatment with montelukast caused cell cycle arrest at G0/G1 phase without inducing apoptosis.

Pranlukast and montelukast inhibited ADAM9 activity and upregulated level of mem-brane-bound MHC class I-related chain A (mMICA).
Arai J, $2021[63]$

$\underline{\text { Urological malignancies }}$

Matsuyama M, 2010 [64]

Matsuyama M, 2009 [65]

Matsuyama M, 2009 [66] human hepatoma cell lines (HepG2, PLC/PRF/5)
All tested cancer cell lines showed CysLT $_{1} \mathrm{R}$ expression, and treatment with montelukast downregulated $\mathrm{CysLT}_{1} \mathrm{R}$ expression, reduced cell viability, and induced early apoptosis in these cells.

T24 cells expressed CysLT 1 R; montelukast induced apoptosis of T24 cells.

NEC-8 expressed CysLT $_{1} R$. Montelukast reduced cell viability and induced apoptosis of NEC-8 cells. 
Table A1. Cont.

\begin{tabular}{cl}
\hline \multicolumn{1}{c}{ Author, Year } & \multicolumn{1}{c}{ Cancer Cells } \\
\hline Matsuyama M, 2007 [67] & $\begin{array}{l}\text { human prostate cancer cell lines (LNCaP, } \\
\text { PC3, DU-145) and normal stromal prostate } \\
\text { cell lines }\end{array}$ \\
\hline Funao K, 2008 [68] & $\begin{array}{l}\text { human renal cell carcinoma cell line (Caki-1) } \\
\text { and normal proximal tubular endothelial } \\
\text { cells }\end{array}$ \\
\end{tabular}

human prostate cancer cell lines (LNCaP,

Tang C, 2018 [69]

PC-3, DU-145) and normal stromal prostate cell lines (NPCs)

\section{Sarveswaran S, 2010 [70]}

Ghosh J, 1998 [71]

Breast cancer

Przylipiak A, 1998 [72]

MCF-7, a human mammary cancer cell line

Hormone-responsive (LNCaP) and -nonresponsive (PC3) human prostate cancer cells
Major Findings

Montelukast significantly inhibited the proliferation and induced apoptosis of prostate cancer cell lines, but not normal stromal prostate cell lines.

Montelukast significantly inhibited the proliferation and induced apoptosis of Caki-1, but not normal proximal tubular endothelial cells.

Montelukast inhibited hypoxia-induced HIF- $1 \alpha$ activation in prostate cancer cells, and inhibited their proliferation. Montelukast also induced downregulation of HIF-1 $\alpha$ under hypoxic conditions, but the effect was not shown by pranlukast and zafirlukast.

MK591, a 5-LO inhibitor developed to inhibit leukotriene biosynthesis, induced apoptosis in LNCaP cells.

Inhibition of 5-LO by MK886 induced massive apoptosis in human prostate cancer cells, LNCaP and PC3.

$\begin{array}{ll}\text { Suknuntha K, 2018 [73] } & \begin{array}{l}\text { MDAMB-231, a triple-negative breast cancer } \\ \text { cell line }\end{array}\end{array}$

Magnusson C, 2011 [74]

Lung cancer

Avis IM, 1996 [75]

human small cell lung cancer cell lines (H209, H345, H82, N417) and human non-small cell lung cancer cell lines (H1155, H23, A549)

Holm JB, 2013 [76]

A549, a human adenocarcinoma cell line breast cancer cell lines (MCF-7, MDA-MB-231)
$\mathrm{LTB}_{4}$ and $\mathrm{LTD}_{4}$ inhibited growth of MCF-7 cells, and leukotriene antagonist LY171883 and 5-LO inhibitor MK886 further lifted the inhibitory effect.

Montelukast and zafirlukast reduced cell viability of MDAMB-231 in a dose-dependent manner. Montelukast mainly induced apoptosis, while zafirlukast mainly exerted its action on cell cycle.

Activating CysLT 2 R signaling with $\mathrm{LTC}_{4}$ did not affect cell proliferation or apoptosis of breast cancer cells but reduced cell migration.

Inhibition of 5-LO resulted in enhanced levels of programmed cell death and significant growth reduction for a number of lung cancer cell lines.

5-LO inhibitors (AA861 or ETH 615-139) and zafirlukast (a CysLT ${ }_{1} \mathrm{R}$ antagonist) blocked the release of organic osmolytes (taurine, meAIB) and the concomitant cell volume restoration following hypoosmotic swelling of A549 cells; inhibition of 5-LO or CysLT 1 R did not affect caspase-3 activity during hypoxia.

Montelukast inhibited the viability/proliferation of lung cancer cells and induced cell death via nuclear translocation of apoptosis-inducing factor. 
Table A1. Cont.

\begin{tabular}{ccc}
\hline Author, Year & Cancer Cells & Major Findings \\
\hline Neurological malignancies & &
\end{tabular}

Neurological malignancies

human neuroblastoma cell lines (SH-SY5Y,

Sveinbjörnsson B, 2008 [78] SK-N-BE2, SK-N-SH, SK-N-AS, SK-N-FI, SK-N-DZ, IMR-32) and a human myelocytic cell line (U937)
All neuroblastoma cell lines expressed CysLT $_{1} R$ and CysLT $_{2} R$. Neuroblastoma cells endogenously produced leukotrienes. $\mathrm{LTD}_{4}$ significantly increased cell viability and proliferation of neuroblastoma cells. Montelukast induced cell cycle arrest and apoptosis of neuroblastoma cells.

Montelukast and zafirlukast inhibited proliferation and induced apoptosis in a concentration-dependent manner in glioblastoma cells; both medications decreased Bcl-2 expression without affecting Bax level. Montelukast induced more apoptosis than zafirlukast in A172 cells, but not in U-87 MG cells; zafirlukast caused cell cycle arrest at G0/G1 phase by upregulating the expression of p53 and p21 and showed a greater antiproliferative effect than montelukast.

Montelukast and zafirlukast, but not zileuton, significantly inhibited migration and invasion of glioblastoma cells, as well as inhibited the expression and activities of MMP-2 and MMP-9.

Other malignancies primary human astrocyte

Uveal melanoma cell lines expressed $\mathrm{CysLT}_{1} \mathrm{R}$ and $\mathrm{CysLT}_{2} \mathrm{R}$. Montelukast, quininib, and 1,4-dihydroxy quininib significantly inhibited uveal melanoma cells in a time- and dosedependent manner, whereas a $\mathrm{CysLT}_{2}$-selective antagonist, HAMI 3379, did not show growth inhibition effect. Quininib significantly inhibited long-term proliferation, altered the cancer secretome of inflammatory and angiogenic factors, and inhibited oxidative phosphorylation.

primary (Mel285, Mel270) and metastatic (OMM2.5) uveal melanoma
$\mathrm{LTC}_{4}$ mediated the second wave of Rac1 activation and cell migration; treatment with 5-LO inhibitors (AA861 and BU-4664L) or CysLT $_{1} \mathrm{R}$ antagonists (MK571 and montelukast), as well as knockdown of CysLT $_{1} R$, suppressed cell migration of A431 cells.

Association between cysteinyl leukotriene pathway and drug resistance

Gekeler V, 1995 [83]

cancer cell line (GLC4/ADR)

Brussel JP, 2004 [84]
PC3 and DU-145, human prostate cancer cell lines
MK571 modulated MRP-associated multidrug resistance in HL60/AR and GLC4/ADR cells.

Prostate cancer cell with multidrug resistant phenotype had increased expression of multidrug-resistance-associated protein 1 (MRP1) and adding MK571, zafirlukast or buthionine sulfoximine significantly increased the sensitivity to cytotoxic drugs. 
Table A1. Cont.

\begin{tabular}{|c|c|c|}
\hline Author, Year & Cancer Cells & Major Findings \\
\hline Nagayama S, 1998 [85] & $\begin{array}{l}\text { human epidermoid carcinoma cell line } \\
\text { (KB-3-1) and its multidrug resistant subclone } \\
\text { (CV 60) }\end{array}$ & $\begin{array}{l}\text { ONO-1078, a } \mathrm{LTD}_{4} \text { receptor antagonist, } \\
\text { inhibited the transporting activity of MRP and } \\
\text { increased the sensitivity to vincristin of CV } 60 \\
\text { and KB-3-1 cells. }\end{array}$ \\
\hline Nakano R, 1998 [86] & NCI-H520, a human lung cancer cell line & $\begin{array}{l}\text { ONO-1078 enhanced the sensitivity of lung } \\
\text { cancer NCI-H520 cells to vincristine, } \\
\text { doxorubicin and etoposide through inhibiting } \\
\text { the function of MRP. }\end{array}$ \\
\hline Satapathy SR, 2020 [87] & $\begin{array}{l}\text { human colon cancer cell lines (HCT116, } \\
\text { HT-29) and their 5-FU-resistant (5-FU-R) cell } \\
\text { lines }\end{array}$ & $\begin{array}{l}\text { The 5-FU-R colon cancer cell lines expressed } \\
\text { increased CysLT } 1 \text { R, which regulated 5-FU } \\
\text { resistance via } \beta \text {-catenin activation and } \\
\text { promoted 5-FU-R-derived stemness. } \\
\text { Montelukast restricted the motility of 5-FU-R } \\
\text { colon cancer cells, sensitized them to 5-FU, and } \\
\text { decreased 5-FU-R-derived stemness. }\end{array}$ \\
\hline
\end{tabular}

Table A2. Selected animal studies investigating the cysteinyl leukotriene pathway in cancer.

\begin{tabular}{ll}
\multicolumn{1}{c}{ Author, Year } & \multicolumn{1}{c}{ Animal Model of Cancer } \\
\hline The role of vascular permeability mediated by cysteinyl leukotrienes \\
\hline Chio CC, $1995[88]$ & Rat C6 glioma model \\
\hline Nozaki M, 2010 [89] & $\begin{array}{l}\text { male Fisher rats, transplantable rat colon } \\
\text { adenocarcinoma RCN9 cells implanted via } \\
\text { the cisterna magna; Lewis lung carcinoma } \\
\text { metastasis model in mice }\end{array}$
\end{tabular}

LTE $_{4}$ selectively opened the blood-tumor barrier and increased the tumor uptake of intravenously injected methotrexate.

Pranlukast, but not montelukast, inhibited tumor cell migration through brain capillary; both pranlukast and montelukast inhibited tumor cell migration through peripheral capillary.

CysLT $_{2} R$ regulated angiogenesis in isolated mouse endothelial cells and in Matrigel implants in mice. The growth and metastases of implanted LLC cells were significantly reduced in $C_{y s} L T_{2} R$-null mice than in

male C57BL/ 6 mice, including wild type,

Duah E, 2019 [90] Cysltr $1^{-/-}$and Cysltr $2^{-/-}$, implanted with Matrigel plugs or subcutaneously injected with Lewis lung carcinoma (LLC) cells wild-type or $C y s L T_{1} R$-null mice. In wild-type mice, the expression of $\mathrm{CysLT}_{2} \mathrm{R}$, but not CysLT $_{1} R$, was increased in tumor vasculature, and BayCysLT 2 (a selective CysLT $_{2} R$ antagonist), but not MK571 (a CysLT 1 R antagonist), reduced tumor growth, angiogenesis and lung metastasis of Lewis lung carcinoma cells in wild-type mice.

\section{Colorectal cancer}

Bellamkonda K, 2018 [57]

a xenograft model of nude mice subcutaneously injected with human colon adenocarcinoma-derived cell lines (HT-29, SW-480)

a nude mouse xenograft model with

Bellamkonda K, 2016 [91] subcutaneous injection of human HCT-116 colon cancer cells
Montelukast significantly inhibited tumor growth and decreased amounts of cancer-stem cells.

$\mathrm{LTD}_{4}$ promoted cancer-initiating cells in initiating tumor growth by allowing immuno-modulation of the tumor microenvironment. 
Table A2. Cont.

Author, Year Animal Model of Cancer $\quad$ Major Findings

Osman J, 2017 [92] $\quad \begin{aligned} & \text { a colitis-associated colon cancer mice model } \\ & \text { induced by azoxymethane/dextran sulfate }\end{aligned}$
sodium

The mice with global disruption of CYSLTR1 gene expression had higher relative body weight, reduction in inflammation, and polyps with lower-grade dysplasia and decreased nuclear expression of $\beta$-catenin and COX-2.

CysLT $_{1} \mathrm{R}$ antagonists (montelukast and a xenograft model of nude mice inoculated with HCT-116 colon cancer cells

ZM198,615) inhibited proliferation and induced apoptosis of tumor cells, resulting in reduced size of the inoculated tumor.

In the tumor xenograft model, 1,4-dihydroxy quininib significantly reduced tumor volume and the expression of angiogenic marker calpain-2.

Butler CT, 2019 [58] mice (Balb/C nu/nu)
Montelukast suppressed pancreatic

a Syrian golden hamster model, using $\mathrm{N}$-nitrosobis (2-oxopropyl) amine (BOP) to induce pancreatic ductal carcinomas carcinogenesis by suppressing cell proliferation via the $\mathrm{LTD}_{4}-\mathrm{CysLT}_{1} \mathrm{R}$ axis.

\section{Lung cancer}

Tsai MJ, 2017 [77]

Gunning WT, 2002 [94]

vinyl carbamate injection to induce lung tumors in mice
Montelukast significantly delayed the tumor growth, as well as decreased Ki-67 expression and increased terminal deoxynucleotidyl transferase dUTP nick end labeling (TUNEL)-positive cells in the tumor tissue.

Leukotriene pathway inhibitors (zafirlukast, MK886, and Zileuton) prevented lung tumor formation and slowed the growth and progression of adenomas to carcinoma.

A later study, using an orthotopic immunocompetent mouse model of lung cancer with Lewis lung carcinoma cells injected into lungs of syngeneic mice, found increased production of leukotrienes $\left(\mathrm{LTB}_{4}\right.$, $\mathrm{LTC}_{4}, \mathrm{LTD}_{4}$ and $\mathrm{LTE}_{4}$ ), in dependent on cytosolic phospholipase $\mathrm{A}_{2}$, in the tumor microenvironment.

$\begin{array}{ll}\text { Neurological malignancies } & \\ \text { Black P, 1998 [96] } & \begin{array}{l}\text { intracerebral C6 glioma in Sprague-Dawley } \\ \text { rats }\end{array}\end{array}$

Pretreatment with $\mathrm{LTC}_{4}$ did significantly extend survival in rats treated with cisplatin

Table A3. Selected clinical studies investigating the cysteinyl leukotriene pathway in cancer.

\begin{tabular}{lll}
\hline \multicolumn{1}{c}{ Author, Year } & \multicolumn{1}{c}{ Patients/Specimens } & \multicolumn{1}{c}{ Major Findings } \\
\hline Hematological malignancies & & $\begin{array}{l}\text { Primary mediastinal B-cell lymphoma was the } \\
\text { only type showing CysLT } \mathrm{R}_{\text {expression in }} \\
\text { tumor cells, while other included lymphomas } \\
\text { showed no CysLT } \mathrm{R}_{1} \text { expression. }\end{array}$ \\
Schain F, 2008 [42] & $\begin{array}{l}\text { lymph node biopsy specimens from } 57 \\
\text { non-Hodgkin lymphoma patients }\end{array}$ & $\begin{array}{l}\text { CysLT }_{1} \mathrm{R}_{\text {was }} \text { expressed by primary Hodgkin } \\
\text { Reed-Sternberg cells. }\end{array}$ \\
\hline Schain F, 2008 [43] & $\begin{array}{l}\text { Specimens from 29 Hodgkin lymphoma } \\
\text { patients }\end{array}$ & \\
\hline
\end{tabular}


Table A3. Cont.

\begin{tabular}{|c|c|c|}
\hline Author, Year & Patients/Specimens & Major Findings \\
\hline Sjölinder M, 2000 [97] & $\begin{array}{l}17 \text { patients in the chronic phase of } \mathrm{Ph} \\
\text { chromosome-positive }(\mathrm{Ph}+) \text { chronic myeloid } \\
\text { leukemia }(\mathrm{CML}) \text { and } 15 \text { healthy } \\
\text { medication-free volunteers }\end{array}$ & $\begin{array}{l}\text { Mature CML CD16 (+) neutrophils had } \\
\text { aberrantly increased expression of } \text { LTC }_{4} \\
\text { synthase. }\end{array}$ \\
\hline
\end{tabular}

Urinary excretion of $\mathrm{LTE}_{4}$ was significantly higher in CML patients than healthy controls. Neutrophilic LTC $_{4}$ synthase expression and activity were markedly elevated and were normalized with imatinib mesylate treatment.

The majority of the single leukemic BCR-ABL ${ }^{+} \mathrm{CD} 34^{+} \mathrm{CD} 38^{-}$cells expressed $\mathrm{CysLT}_{1} \mathrm{R}$ and $\mathrm{CysLT}_{2} \mathrm{R}$, but not ALOX5; treatment with zileuton or montelukast failed to suppress cell growth.

Colorectal cancer

Ohd JF, 2003 [44]

colorectal cancer samples from 84 patients

Using immunohistochemistry and in situ hybridization performed on tissue arrays showed that cysLT $\mathrm{R}_{1}$ expression was significantly associated with poorer survival.

Colorectal cancer tissue showed higher CysLT $_{1} \mathrm{R}$ and 5-LO immunohistochemical Nielsen CK, 2005 [54] specimens from 44 patients with colorectal cancer staining, particular in the nuclei, compared to normal colon tissue; the nuclear accumulation of $\mathrm{CysLT}_{1} \mathrm{R}$ was strongly correlated with stronger staining of proliferative marker Ki-67.

Colon cancer tissue had a significantly lower $\mathrm{CysLT}_{2} \mathrm{R}$ expression than paired normal tissue; lower expression of $\mathrm{CysLT}_{2} \mathrm{R}$ in colon cancer was associated with later stage and poorer prognosis.

The tissue microarray showed that aggressive tumors generally expressed less IFN- $\alpha$ receptor and more EGFR, with a negative correlation between $\mathrm{CysLT}_{2} \mathrm{R}$ and EGFR expression.

Magnusson C, 2011 [60] specimens from 78 colon cancer patients

Higher nuclear expression of $\mathrm{CysLT}_{1} \mathrm{R}$ was associated with a poorer prognosis, whereas higher nuclear expression of $\mathrm{CysLT}_{2} \mathrm{R}$ was associated with a better prognosis. patients

In human ex vivo colorectal cancer tumor explants, 1,4-dihydroxy quininib significantly decreased the secretion of both angiogenic factor TIE-2 and adhesion molecule VCAM-1.

representing Dukes' stage A, B and C colorectal cancer

Esophageal cancer and gastric cancer

esophageal biopsy specimens from 14

Barrett's metaplasia, 2 high-grade dysplasia,

11 esophageal adenocarcinoma and 11 squamous control

Venerito M, 2016 [102]
19 patients with esophageal squamous cell cancer and 9 sex- and age-matched patients with functional dyspepsia
Increased expression levels of $\mathrm{LTB}_{4}$ and CysLTs were found in esophageal adenocarcinoma tissue than in Barrett's metaplasia and control tissues.

Significantly decreased expression levels of CysLT $_{1} \mathrm{R}$ and CysLT $_{2} \mathrm{R}$ were noted in esophageal cancer tissues compared with control squamous epithelium. 
Table A3. Cont.

Author, Year Patients/Specimens Major Findings

Gastric cancer tissue showed significantly increased immunoreactive score of $\mathrm{CysLT}_{1} \mathrm{R}$

Venerito M, 2011 [103]

35 gastric cancer tissue, 29 tumor-free tissue than tumor-free gastric mucosa; intestinal type had more $\mathrm{CysLT}_{1} \mathrm{R}$ and $\mathrm{CysLT}_{2} \mathrm{R}$ expression than the diffuse type.

Remarkably higher circulating LTD $_{4}$ level was

92 hepatocellular carcinoma (HCC) patients noted in HCC patients versus healthy subjects, especially in patients with chronic hepatitis B infection or metastasis.

Zhou Y, 2011 [104]
108 samples of pancreatic ductal adenocarcinoma tissues
Immunohistochemical analyses on pancreatic ductal adenocarcinoma tissues revealed that high $\mathrm{CysLT}_{1} \mathrm{R}$ expression was associated with worse overall survival.

Urological malignancies

tissue specimens from:

58 patients with renal cell carcinoma, paired with normal kidney tissue from 20 patients; 90 patients with bladder cancer, paired with normal bladder tissue from 30 patients;

Matsuyama M, 2010 [64] 151 patients with prostate cancer, 20 patients with prostatic intraepithelial neoplasia, 20 patients with benign prostatic hyperplasia, paired with normal prostate tissue from 20 patients;

30 patients with testicular cancer, paired with normal testis tissue from 10 patients

Matsuyama M, 2009 [65] tissue specimens from 90 transitional cell carcinoma (TCC) patients and 30 patients with normal bladder

tissue specimens from 30 patients with testicular cancer and 10 patients with normal testes

Tumor specimens were obtained from patients with prostate cancer $(n=151)$,

Matsuyama M, 2007 [67] prostatic intraepithelial neoplasia $(n=20)$, benign prostatic hyperplasia $(n=20)$, and normal prostate $(n=20)$

Specimens from 58 patients with renal cell Funao K, 2008 [68] carcinoma and 20 patients with normal kidney tissues
Immunohistochemistry revealed strong CysLT $_{1} \mathrm{R}$ expression in all cancer samples, and more extensive and intense expression was noted in cancer with a higher grade or an advanced stage. Very weak CysLT $_{1} R$ expression was observed in relatively normal tissues.

$\mathrm{CysLT}_{1} \mathrm{R}$ expression was significantly more extensive and intense in TCC specimens, but not in normal bladder tissue; the expression level was greater in higher grade and advanced-stage cancer.

Strong $\mathrm{CysLT}_{1} \mathrm{R}$ expression was observed in testicular cancer specimens, in contrast to weak expression in normal testes.

Prostate cancer tissue had a significantly more extensive and intense $\mathrm{CysLT}_{1} \mathrm{R}$ expression, in nuclei and cytoplasm, than other groups, and the expression was stronger in those with higher Gleason score.

Significantly more extensive and intense

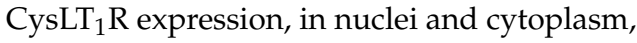
was observed in renal cell carcinoma tissues, compared with normal kidney tissue; the expression of $\mathrm{CysLT}_{1} \mathrm{R}$ was stronger in cancer tissues with higher grade.

Breast cancer

Magnusson C, 2011 [74]

specimens from 144 breast cancer patients

Breast cancers with higher $\mathrm{CysLT}_{1} \mathrm{R}$ and lower CysLT $_{2} \mathrm{R}$ expression levels were associated with higher histological grade and worse overall survival. 
Table A3. Cont.

\begin{tabular}{|c|c|c|}
\hline Author, Year & Patients/Specimens & Major Findings \\
\hline \multicolumn{3}{|l|}{ Other malignancies } \\
\hline Sveinbjörnsson B, 2008 [78] & $\begin{array}{l}27 \text { neuroblastoma surgical specimens, } 3 \\
\text { childhood ganglioneuromas, } 3 \text { samples of } \\
\text { nonmalignant adrenals from children }\end{array}$ & $\begin{array}{l}\text { CysLT }_{1} \mathrm{R} \text { staining was evident in all clinical } \\
\text { tumor specimens and the adjacent vasculature. }\end{array}$ \\
\hline
\end{tabular}

data of 80 primary uveal melanoma samples in The Cancer Genome Atlas (TCGA) and

Slater K, 2020 [81] melanoma in the Liverpool Ocular Oncology Centre

The data from TCGA showed that higher expression of CYSLTR1 and CYSLTR2 genes were significantly associated with poorer disease-free survival and overall survival. However, analysis with tissue microarray of 52 patients only showed poorer overall survival in those with higher $\mathrm{CysLT}_{1} \mathrm{R}$ expression but $\mathrm{CysLT}_{2} \mathrm{R}$ expression was not associated with survival.

Chemopreventive effects of cysteinyl leukotriene inhibition

Tsai MJ, 2016 [105]
4185 CysLTR antagonist (LTRA) users and 20,925 LTRA non-users from Taiwan National Health Insurance Research Database
LTRA use decreased cancer risk in a dose-dependent manner in asthma patients. The chemopreventive effect of LTRA was markedly observed in terms of lung, colorectal, liver and breast cancer.

Patients with leukotriene pathway inhibiting medication (montelukast, zafirlukast, or zileuton) exposure had a significantly reduced risk of lung cancer than those without exposure.
23,730 patients with leukotriene pathway inhibiting medication exposure and 534,736 patients from the data from the Department of Veteran Affairs

\section{References}

1. Hsiao, A.J.; Chen, L.H.; Lu, T.H. Ten leading causes of death in Taiwan: A comparison of two grouping lists. J. Formos Med. Assoc. 2015, 114, 679-680. [CrossRef]

2. World Health Organization. Cancer. Available online: https://www.who.int/news-room/fact-sheets/detail/cancer (accessed on 15 November 2021).

3. Robert, C. A decade of immune-checkpoint inhibitors in cancer therapy. Nat. Commun. 2020, 11, 3801. [CrossRef] [PubMed]

4. Balkwill, F.R.; Capasso, M.; Hagemann, T. The tumor microenvironment at a glance. J. Cell Sci. 2012, 125, 5591-5596. [CrossRef] [PubMed]

5. Kurose, K.; Hoshaw-Woodard, S.; Adeyinka, A.; Lemeshow, S.; Watson, P.H.; Eng, C. Genetic model of multi-step breast carcinogenesis involving the epithelium and stroma: Clues to tumour-microenvironment interactions. Hum. Mol. Genet. 2001, 10, 1907-1913. [CrossRef] [PubMed]

6. Tian, W.; Jiang, X.; Kim, D.; Guan, T.; Nicolls, M.R.; Rockson, S.G. Leukotrienes in Tumor-Associated Inflammation. Front. Pharmacol. 2020, 11, 1289. [CrossRef] [PubMed]

7. Peters-Golden, M.; Gleason, M.M.; Togias, A. Cysteinyl leukotrienes: Multi-functional mediators in allergic rhinitis. Clin. Exp. Allergy 2006, 36, 689-703. [CrossRef]

8. Ophir, J.; Brenner, S.; Kivity, S. Leukotrienes. Int. J. Dermatol. 1985, 24, 199-203. [CrossRef] [PubMed]

9. Peters-Golden, M.; Brock, T.G. 5-lipoxygenase and FLAP. Prostaglandins Leukot. Essent. Fat. Acids 2003, 69, 99-109. [CrossRef]

10. Haeggstrom, J.Z.; Kull, F.; Rudberg, P.C.; Tholander, F.; Thunnissen, M.M. Leukotriene A4 hydrolase. Prostaglandins Other Lipid Mediat. 2002, 68-69, 495-510. [CrossRef]

11. Peters-Golden, M.; Henderson, W.R., Jr. Leukotrienes. N. Engl. J. Med. 2007, 357, 1841-1854. [CrossRef]

12. Al-Azzam, N.; Elsalem, L. Leukotriene D4 role in allergic asthma pathogenesis from cellular and therapeutic perspectives. Life Sci. 2020, 260, 118452. [CrossRef] [PubMed]

13. Crooks, S.W.; Stockley, R.A. Leukotriene B4. Int. J. Biochem. Cell Biol. 1998, 30, 173-178. [CrossRef]

14. Singh, R.K.; Gupta, S.; Dastidar, S.; Ray, A. Cysteinyl leukotrienes and their receptors: Molecular and functional characteristics. Pharmacology 2010, 85, 336-349. [CrossRef]

15. Lam, B.K.; Austen, K.F. Leukotriene C4 synthase: A pivotal enzyme in cellular biosynthesis of the cysteinyl leukotrienes. Prostaglandins Other Lipid Mediat. 2002, 68, 511-520. [CrossRef] 
16. Chan, C.C.; Ecclestone, P.; Nicholson, D.W.; Metters, K.M.; Pon, D.J.; Rodger, I.W. Leukotriene D4-induced increases in cytosolic calcium in THP-1 cells: Dependence on extracellular calcium and inhibition with selective leukotriene D4 receptor antagonists. J. Pharmacol. Exp. Ther. 1994, 269, 891-896.

17. Hoshino, M.; Izumi, T.; Shimizu, T. Leukotriene D4 activates mitogen-activated protein kinase through a protein kinase CalphaRaf-1-dependent pathway in human monocytic leukemia THP-1 cells. J. Biol. Chem. 1998, 273, 4878-4882. [CrossRef]

18. Ali, A.; Ford-Hutchinson, A.W.; Nicholson, D.W. Activation of protein kinase C down-regulates leukotriene C4 synthase activity and attenuates cysteinyl leukotriene production in an eosinophilic substrain of HL-60 cells. J. Immunol. 1994, 153, 776-788.

19. Murphy, A.G.; Casey, R.; Maguire, A.; Tosetto, M.; Butler, C.T.; Conroy, E.; Reynolds, A.L.; Sheahan, K.; O’Donoghue, D.; Gallagher, W.M.; et al. Preclinical validation of the small molecule drug quininib as a novel therapeutic for colorectal cancer. Sci. Rep. 2016, 6, 34523. [CrossRef]

20. Burke, L.; Butler, C.T.; Murphy, A.; Moran, B.; Gallagher, W.M.; O'Sullivan, J.; Kennedy, B.N. Evaluation of Cysteinyl Leukotriene Signaling as a Therapeutic Target for Colorectal Cancer. Front. Cell Dev. Biol. 2016, 4, 103. [CrossRef]

21. Tsopanoglou, N.E.; Pipili-Synetos, E.; Maragoudakis, M.E. Leukotrienes C4 and D4 promote angiogenesis via a receptor-mediated interaction. Eur. J. Pharmacol. 1994, 258, 151-154. [CrossRef]

22. Rovati, G.E.; Capra, V. Cysteinyl-leukotriene receptors and cellular signals. Sci. World J. 2007, 7, 1375-1392. [CrossRef]

23. Ravasi, S.; Citro, S.; Viviani, B.; Capra, V.; Rovati, G.E. CysLT 1 receptor-induced human airway smooth muscle cells proliferation requires ROS generation, EGF receptor transactivation and ERK1/2 phosphorylation. Respir Res. 2006, 7, 42. [CrossRef]

24. Profita, M.; Sala, A.; Bonanno, A.; Siena, L.; Ferraro, M.; Di Giorgi, R.; Montalbano, A.M.; Albano, G.D.; Gagliardo, R.; Gjomarkaj, M. Cysteinyl leukotriene-1 receptor activation in a human bronchial epithelial cell line leads to signal transducer and activator of transcription 1-mediated eosinophil adhesion. J. Pharmacol. Exp. Ther. 2008, 325, 1024-1030. [CrossRef]

25. Winkler, J.D.; Sarau, H.M.; Foley, J.J.; Crooke, S.T. Leukotriene D4-induced homologous desensitization in basal and differentiated U-937 cells: Characterization with the partial agonist leukotriene E4 and assessment of receptor reserve. J. Pharmacol. Exp. Ther. 1988, 247, 54-62.

26. Snetkov, V.A.; Hapgood, K.J.; McVicker, C.G.; Lee, T.H.; Ward, J.P. Mechanisms of leukotriene D4-induced constriction in human small bronchioles. Br. J. Pharmacol. 2001, 133, 243-252. [CrossRef]

27. Wang, X.Y.; Tang, S.S.; Hu, M.; Long, Y.; Li, Y.Q.; Liao, M.X.; Ji, H.; Hong, H. Leukotriene D4 induces amyloid-beta generation via CysLT(1)R-mediated NF-kappaB pathways in primary neurons. Neurochem. Int. 2013, 62, 340-347. [CrossRef]

28. Heise, C.E.; O’Dowd, B.F.; Figueroa, D.J.; Sawyer, N.; Nguyen, T.; Im, D.S.; Stocco, R.; Bellefeuille, J.N.; Abramovitz, M.; Cheng, R.; et al. Characterization of the human cysteinyl leukotriene 2 receptor. J. Biol. Chem. 2000, 275, 30531-30536. [CrossRef]

29. Sjostrom, M.; Johansson, A.S.; Schroder, O.; Qiu, H.; Palmblad, J.; Haeggstrom, J.Z. Dominant expression of the CysLT 2 receptor accounts for calcium signaling by cysteinyl leukotrienes in human umbilical vein endothelial cells. Arterioscler. Thromb. Vasc. Biol. 2003, 23, e37-e41. [CrossRef]

30. Zhao, R.; Ying, M.; Gu, S.; Yin, W.; Li, Y.; Yuan, H.; Fang, S.; Li, M. Cysteinyl Leukotriene Receptor 2 is Involved in Inflammation and Neuronal Damage by Mediating Microglia M1/M2 Polarization through NF-kappaB Pathway. Neuroscience 2019, 422, 99-118. [CrossRef]

31. Liu, T.; Barrett, N.A.; Kanaoka, Y.; Buchheit, K.; Laidlaw, T.M.; Garofalo, D.; Lai, J.; Katz, H.R.; Feng, C.; Boyce, J.A. Cysteinyl leukotriene receptor 2 drives lung immunopathology through a platelet and high mobility box 1-dependent mechanism. Mucosal Immunol. 2019, 12, 679-690. [CrossRef]

32. Kanaoka, Y.; Maekawa, A.; Austen, K.F. Identification of GPR99 protein as a potential third cysteinyl leukotriene receptor with a preference for leukotriene E4 ligand. J. Biol. Chem. 2013, 288, 10967-10972. [CrossRef]

33. Bankova, L.G.; Lai, J.; Yoshimoto, E.; Boyce, J.A.; Austen, K.F.; Kanaoka, Y.; Barrett, N.A. Leukotriene E4 elicits respiratory epithelial cell mucin release through the G-protein-coupled receptor, GPR99. Proc. Natl. Acad. Sci. USA 2016, 113, 6242-6247. [CrossRef]

34. Bankova, L.G.; Dwyer, D.F.; Yoshimoto, E.; Ualiyeva, S.; McGinty, J.W.; Raff, H.; von Moltke, J.; Kanaoka, Y.; Frank Austen, K.; Barrett, N.A. The cysteinyl leukotriene 3 receptor regulates expansion of IL-25-producing airway brush cells leading to type 2 inflammation. Sci. Immunol. 2018, 3, eaat9453. [CrossRef]

35. Godson, C. Balancing the Effect of Leukotrienes in Asthma. N. Engl. J. Med. 2020, 382, 1472-1475. [CrossRef]

36. Mong, S.; Wu, H.L.; Wong, A.; Sarau, H.M.; Crooke, S.T. Leukotriene D4 receptor-mediated phosphoinositol hydrolysis and calcium mobilization in rat basophilic leukemic cells. J. Pharmacol. Exp. Ther. 1988, 247, 803-813.

37. Stenke, L.; Reizenstein, P.; Lindgren, J.A. Increased leukotriene C4 production in chronic myelogenous leukemia. Acta Oncol. 1988, 27, 803-805. [CrossRef]

38. Stenke, L.; Samuelsson, J.; Palmblad, J.; Dabrowski, L.; Reizenstein, P.; Lindgren, J.A. Elevated white blood cell synthesis of leukotriene C4 in chronic myelogenous leukaemia but not in polycythaemia vera. Br. J. Haematol. 1990, 74, 257-263. [CrossRef]

39. Yektaei-Karin, E.; Zovko, A.; Nilsson, A.; Nasman-Glaser, B.; Kanter, L.; Radmark, O.; Wallvik, J.; Ekblom, M.; Dolinska, M.; Qian, H.; et al. Modulation of leukotriene signaling inhibiting cell growth in chronic myeloid leukemia. Leuk. Lymphoma 2017, 58, 1903-1913. [CrossRef]

40. Zovko, A.; Yektaei-Karin, E.; Salamon, D.; Nilsson, A.; Wallvik, J.; Stenke, L. Montelukast, a cysteinyl leukotriene receptor antagonist, inhibits the growth of chronic myeloid leukemia cells through apoptosis. Oncol. Rep. 2018, 40, 902-908. [CrossRef] 
41. Drost, A.C.; Seitz, G.; Boehmler, A.; Funk, M.; Norz, K.P.; Zipfel, A.; Xue, X.; Kanz, L.; Mohle, R. The G protein-coupled receptor CysLT $_{1}$ mediates chemokine-like effects and prolongs survival in chronic lymphocytic leukemia. Leuk. Lymphoma 2012, 53, 665-673. [CrossRef]

42. Schain, F.; Schain, D.; Mahshid, Y.; Liu, C.; Porwit, A.; Xu, D.; Claesson, H.E.; Sundstrom, C.; Bjorkholm, M.; Sjoberg, J. Differential expression of cysteinyl leukotriene receptor 1 and 15-lipoxygenase-1 in non-Hodgkin lymphomas. Clin. Lymphoma Myeloma 2008, 8, 340-347. [CrossRef]

43. Schain, F.; Tryselius, Y.; Sjoberg, J.; Porwit, A.; Backman, L.; Malec, M.; Xu, D.; Vockerodt, M.; Baumforth, K.R.; Wei, W.; et al. Evidence for a pathophysiological role of cysteinyl leukotrienes in classical Hodgkin lymphoma. Int. J. Cancer 2008, 123, 2285-2293. [CrossRef]

44. Ohd, J.F.; Nielsen, C.K.; Campbell, J.; Landberg, G.; Lofberg, H.; Sjolander, A. Expression of the leukotriene D4 receptor CysLT 1 , COX-2, and other cell survival factors in colorectal adenocarcinomas. Gastroenterology 2003, 124, 57-70. [CrossRef]

45. Nielsen, C.K.; Ohd, J.F.; Wikstrom, K.; Massoumi, R.; Paruchuri, S.; Juhas, M.; Sjolander, A. The leukotriene receptor CysLT 1 and 5-lipoxygenase are upregulated in colon cancer. Adv. Exp. Med. Biol. 2003, 525, 201-204.

46. Wikstrom, K.; Juhas, M.; Sjolander, A. The anti-apoptotic effect of leukotriene D4 involves the prevention of caspase 8 activation and Bid cleavage. Biochem. J. 2003, 371, 115-124. [CrossRef]

47. Paruchuri, S.; Hallberg, B.; Juhas, M.; Larsson, C.; Sjolander, A. Leukotriene D(4) activates MAPK through a Ras-independent but PKCepsilon-dependent pathway in intestinal epithelial cells. J. Cell Sci. 2002, 115, 1883-1893. [CrossRef]

48. Wikstrom, K.; Ohd, J.F.; Sjolander, A. Regulation of leukotriene-dependent induction of cyclooxygenase-2 and Bcl-2. Biochem. Biophys. Res. Commun. 2003, 302, 330-335. [CrossRef]

49. Parhamifar, L.; Jeppsson, B.; Sjolander, A. Activation of cPLA2 is required for leukotriene D4-induced proliferation in colon cancer cells. Carcinogenesis 2005, 26, 1988-1998. [CrossRef]

50. Mezhybovska, M.; Wikstrom, K.; Ohd, J.F.; Sjolander, A. The inflammatory mediator leukotriene D4 induces beta-catenin signaling and its association with antiapoptotic Bcl-2 in intestinal epithelial cells. J. Biol. Chem. 2006, 281, 6776-6784. [CrossRef]

51. Mezhybovska, M.; Yudina, Y.; Abhyankar, A.; Sjolander, A. Beta-catenin is involved in alterations in mitochondrial activity in non-transformed intestinal epithelial and colon cancer cells. Br. J. Cancer 2009, 101, 1596-1605. [CrossRef]

52. Paruchuri, S.; Broom, O.; Dib, K.; Sjolander, A. The pro-inflammatory mediator leukotriene D4 induces phosphatidylinositol 3-kinase and Rac-dependent migration of intestinal epithelial cells. J. Biol. Chem. 2005, 280, 13538-13544. [CrossRef]

53. Salim, T.; Sand-Dejmek, J.; Sjolander, A. The inflammatory mediator leukotriene D4 induces subcellular beta-catenin translocation and migration of colon cancer cells. Exp. Cell Res. 2014, 321, 255-266. [CrossRef]

54. Nielsen, C.K.; Campbell, J.I.; Ohd, J.F.; Morgelin, M.; Riesbeck, K.; Landberg, G.; Sjolander, A. A novel localization of the G-protein-coupled CysLT 1 receptor in the nucleus of colorectal adenocarcinoma cells. Cancer Res. 2005, 65, 732-742.

55. Yudina, Y.; Parhamifar, L.; Bengtsson, A.M.; Juhas, M.; Sjolander, A. Regulation of the eicosanoid pathway by tumour necrosis factor alpha and leukotriene D4 in intestinal epithelial cells. Prostaglandins Leukot. Essent. Fat. Acids 2008, 79, 223-231. [CrossRef]

56. Paruchuri, S.; Mezhybovska, M.; Juhas, M.; Sjolander, A. Endogenous production of leukotriene D4 mediates autocrine survival and proliferation via CysLT 1 receptor signalling in intestinal epithelial cells. Oncogene 2006, 25, 6660-6665. [CrossRef]

57. Bellamkonda, K.; Satapathy, S.R.; Douglas, D.; Chandrashekar, N.; Selvanesan, B.C.; Liu, M.; Savari, S.; Jonsson, G.; Sjolander, A. Montelukast, a CysLT 1 receptor antagonist, reduces colon cancer stemness and tumor burden in a mouse xenograft model of human colon cancer. Cancer Lett. 2018, 437, 13-24. [CrossRef]

58. Butler, C.T.; Kennedy, S.A.; Buckley, A.; Doyle, R.; Conroy, E.; Gallagher, W.M.; O'Sullivan, J.; Kennedy, B.N. 1,4-dihydroxy quininib attenuates growth of colorectal cancer cells and xenografts and regulates the TIE-2 signaling pathway in patient tumours. Oncotarget 2019, 10, 3725-3744. [CrossRef]

59. Magnusson, C.; Ehrnstrom, R.; Olsen, J.; Sjolander, A. An increased expression of cysteinyl leukotriene 2 receptor in colorectal adenocarcinomas correlates with high differentiation. Cancer Res. 2007, 67, 9190-9198. [CrossRef]

60. Magnusson, C.; Bengtsson, A.M.; Liu, M.; Liu, J.; Ceder, Y.; Ehrnstrom, R.; Sjolander, A. Regulation of cysteinyl leukotriene receptor 2 expression-a potential anti-tumor mechanism. PLoS ONE 2011, 6, e29060. [CrossRef]

61. Bengtsson, A.M.; Jonsson, G.; Magnusson, C.; Salim, T.; Axelsson, C.; Sjolander, A. The cysteinyl leukotriene 2 receptor contributes to all-trans retinoic acid-induced differentiation of colon cancer cells. BMC Cancer 2013, 13, 336. [CrossRef]

62. Kachi, K.; Kato, H.; Naiki-Ito, A.; Komura, M.; Nagano-Matsuo, A.; Naitoh, I.; Hayashi, K.; Kataoka, H.; Inaguma, S.; Takahashi, S. Anti-Allergic Drug Suppressed Pancreatic Carcinogenesis via Down-Regulation of Cellular Proliferation. Int. J. Mol. Sci. 2021, 22, 7444. [CrossRef] [PubMed]

63. Arai, J.; Goto, K.; Otoyama, Y.; Nakajima, Y.; Sugiura, I.; Kajiwara, A.; Tojo, M.; Ichikawa, Y.; Uozumi, S.; Shimozuma, Y.; et al. Leukotriene receptor antagonists enhance HCC treatment efficacy by inhibiting ADAMs and suppressing MICA shedding. Cancer Immunol. Immunother. 2021, 70, 203-213. [CrossRef]

64. Matsuyama, M.; Yoshimura, R. Cysteinyl-leukotriene1 receptor is a potent target for the prevention and treatment of human urological cancer. Mol. Med. Rep. 2010, 3, 245-251. [CrossRef] [PubMed]

65. Matsuyama, M.; Funao, K.; Hayama, T.; Tanaka, T.; Kawahito, Y.; Sano, H.; Takemoto, Y.; Nakatani, T.; Yoshimura, R. Relationship between cysteinyl-leukotriene-1 receptor and human transitional cell carcinoma in bladder. Urology 2009, 73, 916-921. [CrossRef] [PubMed] 
66. Matsuyama, M.; Funao, K.; Kawahito, Y.; Sano, H.; Chargui, J.; Touraine, J.L.; Nakatani, T.; Yoshimura, R. Expression of cysteinylLT1 receptor in human testicular cancer and growth reduction by its antagonist through apoptosis. Mol. Med. Rep. 2009, 2, 163-167. [CrossRef] [PubMed]

67. Matsuyama, M.; Hayama, T.; Funao, K.; Kawahito, Y.; Sano, H.; Takemoto, Y.; Nakatani, T.; Yoshimura, R. Overexpression of cysteinyl LT1 receptor in prostate cancer and $\mathrm{CysLT}_{1} \mathrm{R}$ antagonist inhibits prostate cancer cell growth through apoptosis. Oncol. Rep. 2007, 18, 99-104. [CrossRef]

68. Funao, K.; Matsuyama, M.; Naganuma, T.; Kawahito, Y.; Sano, H.; Nakatani, T.; Yoshimura, R. The cysteinylLT1 receptor in human renal cell carcinoma. Mol. Med. Rep. 2008, 1, 185-189.

69. Tang, C.; Lei, H.; Zhang, J.; Liu, M.; Jin, J.; Luo, H.; Xu, H.; Wu, Y. Montelukast inhibits hypoxia inducible factor-1alpha translation in prostate cancer cells. Cancer Biol. Ther. 2018, 19, 715-721. [CrossRef]

70. Sarveswaran, S.; Myers, C.E.; Ghosh, J. MK591, a leukotriene biosynthesis inhibitor, induces apoptosis in prostate cancer cells: Synergistic action with LY294002, an inhibitor of phosphatidylinositol 3'-kinase. Cancer Lett. 2010, 291, 167-176. [CrossRef]

71. Ghosh, J.; Myers, C.E. Inhibition of arachidonate 5-lipoxygenase triggers massive apoptosis in human prostate cancer cells. Proc. Natl. Acad. Sci. USA 1998, 95, 13182-13187. [CrossRef]

72. Przylipiak, A.; Hafner, J.; Przylipiak, J.; Runnebaum, B.; Rabe, T.; Kohn, F.M. Influence of leukotrienes on in vitro growth of human mammary carcinoma cell line MCF-7. Eur. J. Obstet. Gynecol. Reprod. Biol. 1998, 77, 61-65. [CrossRef]

73. Suknuntha, K.; Yubolphan, R.; Krueaprasertkul, K.; Srihirun, S.; Sibmooh, N.; Vivithanaporn, P. Leukotriene Receptor Antagonists Inhibit Mitogenic Activity in Triple Negative Breast Cancer Cells. Asian Pac. J. Cancer Prev. 2018, 19, 833-837. [CrossRef] [PubMed]

74. Magnusson, C.; Liu, J.; Ehrnstrom, R.; Manjer, J.; Jirstrom, K.; Andersson, T.; Sjolander, A. Cysteinyl leukotriene receptor expression pattern affects migration of breast cancer cells and survival of breast cancer patients. Int. J. Cancer 2011, 129, 9-22. [CrossRef] [PubMed]

75. Avis, I.M.; Jett, M.; Boyle, T.; Vos, M.D.; Moody, T.; Treston, A.M.; Martinez, A.; Mulshine, J.L. Growth control of lung cancer by interruption of 5-lipoxygenase-mediated growth factor signaling. J. Clin. Investig. 1996, 97, 806-813. [CrossRef]

76. Holm, J.B.; Grygorczyk, R.; Lambert, I.H. Volume-sensitive release of organic osmolytes in the human lung epithelial cell line A549: Role of the 5-lipoxygenase. Am. J. Physiol. Cell Physiol. 2013, 305, C48-C60. [CrossRef]

77. Tsai, M.J.; Chang, W.A.; Tsai, P.H.; Wu, C.Y.; Ho, Y.W.; Yen, M.C.; Lin, Y.S.; Kuo, P.L.; Hsu, Y.L. Montelukast Induces ApoptosisInducing Factor-Mediated Cell Death of Lung Cancer Cells. Int. J. Mol. Sci. 2017, 18, 1353. [CrossRef]

78. Sveinbjornsson, B.; Rasmuson, A.; Baryawno, N.; Wan, M.; Pettersen, I.; Ponthan, F.; Orrego, A.; Haeggstrom, J.Z.; Johnsen, J.I.; Kogner, P. Expression of enzymes and receptors of the leukotriene pathway in human neuroblastoma promotes tumor survival and provides a target for therapy. FASEB J. Off. Publ. Fed. Am. Soc. Exp. Biol. 2008, 22, 3525-3536. [CrossRef]

79. Piromkraipak, P.; Parakaw, T.; Phuagkhaopong, S.; Srihirun, S.; Chongthammakun, S.; Chaithirayanon, K.; Vivithanaporn, P. Cysteinyl leukotriene receptor antagonists induce apoptosis and inhibit proliferation of human glioblastoma cells by downregulating B-cell lymphoma 2 and inducing cell cycle arrest. Can. J. Physiol. Pharmacol. 2018, 96, 798-806. [CrossRef]

80. Piromkraipak, P.; Sangpairoj, K.; Tirakotai, W.; Chaithirayanon, K.; Unchern, S.; Supavilai, P.; Power, C.; Vivithanaporn, P. Cysteinyl Leukotriene Receptor Antagonists Inhibit Migration, Invasion, and Expression of MMP-2/9 in Human Glioblastoma. Cell Mol. Neurobiol. 2018, 38, 559-573. [CrossRef]

81. Slater, K.; Heeran, A.B.; Garcia-Mulero, S.; Kalirai, H.; Sanz-Pamplona, R.; Rahman, A.; Al-Attar, N.; Helmi, M.; O’Connell, F.; Bosch, R.; et al. High Cysteinyl Leukotriene Receptor 1 Expression Correlates with Poor Survival of Uveal Melanoma Patients and Cognate Antagonist Drugs Modulate the Growth, Cancer Secretome, and Metabolism of Uveal Melanoma Cells. Cancers 2020, 12, 2950. [CrossRef]

82. Magi, S.; Takemoto, Y.; Kobayashi, H.; Kasamatsu, M.; Akita, T.; Tanaka, A.; Takano, K.; Tashiro, E.; Igarashi, Y.; Imoto, M. 5-Lipoxygenase and cysteinyl leukotriene receptor 1 regulate epidermal growth factor-induced cell migration through Tiam1 upregulation and Rac1 activation. Cancer Sci. 2013, 105, 290-296. [CrossRef]

83. Gekeler, V.; Ise, W.; Sanders, K.H.; Ulrich, W.R.; Beck, J. The leukotriene LTD4 receptor antagonist MK571 specifically modulates MRP associated multidrug resistance. Biochem. Biophys. Res. Commun. 1995, 208, 345-352. [CrossRef]

84. van Brussel, J.P.; Oomen, M.A.; Vossebeld, P.J.; Wiemer, E.A.; Sonneveld, P.; Mickisch, G.H. Identification of multidrug resistanceassociated protein 1 and glutathione as multidrug resistance mechanisms in human prostate cancer cells: Chemosensitization with leukotriene D4 antagonists and buthionine sulfoximine. BJU Int. 2004, 93, 1333-1338. [CrossRef] [PubMed]

85. Nagayama, S.; Chen, Z.S.; Kitazono, M.; Takebayashi, Y.; Niwa, K.; Yamada, K.; Tani, A.; Haraguchi, M.; Sumizawa, T.; Furukawa, T.; et al. Increased sensitivity to vincristine of MDR cells by the leukotriene D4 receptor antagonist, ONO-1078. Cancer Lett. 1998, 130, 175-182. [CrossRef]

86. Nakano, R.; Oka, M.; Nakamura, T.; Fukuda, M.; Kawabata, S.; Terashi, K.; Tsukamoto, K.; Noguchi, Y.; Soda, H.; Kohno, S. A leukotriene receptor antagonist, ONO-1078, modulates drug sensitivity and leukotriene C4 efflux in lung cancer cells expressing multidrug resistance protein. Biochem. Biophys. Res. Commun. 1998, 251, 307-312. [CrossRef] [PubMed]

87. Satapathy, S.R.; Sjolander, A. Cysteinyl leukotriene receptor 1 promotes 5-fluorouracil resistance and resistance-derived stemness in colon cancer cells. Cancer Lett. 2020, 488, 50-62. [CrossRef]

88. Chio, C.C.; Lin, S.J.; Lin, M.T. Leukotriene E4 selectively increase the delivery of methotrexate to the C6 gliomas in rats. J. Neuro-Oncol. 1995, 25, 89-95. [CrossRef] 
89. Nozaki, M.; Yoshikawa, M.; Ishitani, K.; Kobayashi, H.; Houkin, K.; Imai, K.; Ito, Y.; Muraki, T. Cysteinyl leukotriene receptor antagonists inhibit tumor metastasis by inhibiting capillary permeability. Keio J. Med. 2010, 59, 10-18. [CrossRef]

90. Duah, E.; Teegala, L.R.; Kondeti, V.; Adapala, R.K.; Keshamouni, V.G.; Kanaoka, Y.; Austen, K.F.; Thodeti, C.K.; Paruchuri, S. Cysteinyl leukotriene 2 receptor promotes endothelial permeability, tumor angiogenesis, and metastasis. Proc. Natl. Acad. Sci. USA 2019, 116, 199-204. [CrossRef]

91. Bellamkonda, K.; Chandrashekar, N.K.; Osman, J.; Selvanesan, B.C.; Savari, S.; Sjolander, A. The eicosanoids leukotriene D4 and prostaglandin $\mathrm{E} 2$ promote the tumorigenicity of colon cancer-initiating cells in a xenograft mouse model. BMC cancer 2016, 16, 1-14. [CrossRef]

92. Osman, J.; Savari, S.; Chandrashekar, N.K.; Bellamkonda, K.; Douglas, D.; Sjolander, A. Cysteinyl leukotriene receptor 1 facilitates tumorigenesis in a mouse model of colitis-associated colon cancer. Oncotarget 2017, 8, 34773. [CrossRef] [PubMed]

93. Savari, S.; Liu, M.; Zhang, Y.; Sime, W.; Sjolander, A. CysLT(1)R antagonists inhibit tumor growth in a xenograft model of colon cancer. PLoS ONE 2013, 8, e73466. [CrossRef] [PubMed]

94. Gunning, W.T.; Kramer, P.M.; Steele, V.E.; Pereira, M.A. Chemoprevention by lipoxygenase and leukotriene pathway inhibitors of vinyl carbamate-induced lung tumors in mice. Cancer Res. 2002, 62, 4199-4201. [PubMed]

95. Poczobutt, J.M.; Gijon, M.; Amin, J.; Hanson, D.; Li, H.; Walker, D.; Weiser-Evans, M.; Lu, X.; Murphy, R.C.; Nemenoff, R.A Eicosanoid profiling in an orthotopic model of lung cancer progression by mass spectrometry demonstrates selective production of leukotrienes by inflammatory cells of the microenvironment. PLoS ONE 2013, 8, e79633. [CrossRef]

96. Black, P.; Hand, C.M.; Vender, J.R.; Finkelstein, S.D. Chemotherapy in experimental brain tumor, part 2: Pretreatment with leukotriene C4 prolongs survival. J. Neuro-Oncol. 1998, 36, 7-19. [CrossRef]

97. Sjolinder, M.; Stenke, L.; Nasman-Glaser, B.; Widell, S.; Doucet, J.; Jakobsson, P.J.; Lindgren, J.A. Aberrant expression of active leukotriene $\mathrm{C}(4)$ synthase in CD16(+) neutrophils from patients with chronic myeloid leukemia. Blood 2000, 95, 1456-1464. [CrossRef]

98. Roos, C.; Stenke, L.; Ohm, L.; Widell, S.; Kumlin, M.; Lindgren, J.A.; Tornhamre, S. Clinical imatinib mesylate treatment induces early normalisation of aberrant neutrophil leukotriene C4 synthase expression and activity in chronic myeloid leukaemia. Br. $J$. Haematol. 2008, 142, 992-995. [CrossRef]

99. Dolinska, M.; Piccini, A.; Wong, W.M.; Gelali, E.; Johansson, A.S.; Klang, J.; Xiao, P.; Yektaei-Karin, E.; Stromberg, U.O.; Mustjoki, S.; et al. Leukotriene signaling via ALOX5 and cysteinyl leukotriene receptor 1 is dispensable for in vitro growth of CD34(+)CD38(-) stem and progenitor cells in chronic myeloid leukemia. Biochem. Biophys. Res. Commun. 2017, 490, 378-384. [CrossRef] [PubMed]

100. Magnusson, C.; Mezhybovska, M.; Lorinc, E.; Fernebro, E.; Nilbert, M.; Sjolander, A. Low expression of CysLT $_{1} \mathrm{R}_{\text {and }}$ high expression of $\mathrm{CysLT}_{2} \mathrm{R}$ mediate good prognosis in colorectal cancer. Eur. J. Cancer 2010, 46, 826-835. [CrossRef]

101. Shutt, J.D.; Boger, P.; Neale, J.R.; Patel, P.; Sampson, A.P. Activity of the leukotriene pathway in Barrett's metaplasia and oesophageal adenocarcinoma. Inflamm. Res. 2012, 61, 1379-1384. [CrossRef]

102. Venerito, M.; Helmke, C.; Jechorek, D.; Wex, T.; Rosania, R.; Antweiler, K.; Weigt, J.; Malfertheiner, P. Leukotriene receptor expression in esophageal squamous cell cancer and non-transformed esophageal epithelium: A matched case control study. BMC Gastroenterol. 2016, 16, 85. [CrossRef] [PubMed]

103. Venerito, M.; Kuester, D.; Harms, C.; Schubert, D.; Wex, T.; Malfertheiner, P. Upregulation of leukotriene receptors in gastric cancer. Cancers 2011, 3, 3156-3168. [CrossRef] [PubMed]

104. Zhou, Y.; Guo, D.; Li, H.; Jie, S. Circulating LTD4 in patients with hepatocellular carcinoma. Tumor Biol. 2011, 32, 139-144. [CrossRef]

105. Tsai, M.J.; Wu, P.H.; Sheu, C.C.; Hsu, Y.L.; Chang, W.A.; Hung, J.Y.; Yang, C.J.; Yang, Y.H.; Kuo, P.L.; Huang, M.S. Cysteinyl Leukotriene Receptor Antagonists Decrease Cancer Risk in Asthma Patients. Sci. Rep. 2016, 6, 23979. [CrossRef]

106. Sutton, S.S.; Magagnoli, J.; Cummings, T.H.; Hardin, J.W. Leukotriene inhibition and the risk of lung cancer among U.S. veterans with asthma. Pulm. Pharmacol. Ther. 2021, 71, 102084. [CrossRef] [PubMed] 